\title{
Five new species of the open-holed trapdoor spider genus Aname (Araneae: Mygalomorphae: Anamidae) from Western Australia, with a revised generic placement for Aname armigera
}

\author{
Mark S. Harvey ${ }^{1,2}$, Karl Gruber ${ }^{2}$, Mia J. Hillyer ${ }^{1}$ and Joel A. Huey ${ }^{1,2,3,4}$ \\ ${ }^{1}$ Collections and Research, Western Australian Museum, 49 Kew Street, Welshpool, Western \\ Australia 6106, Australia. \\ ${ }^{2}$ School of Biological Sciences, University of Western Australia, Crawley, Western Australia 6009, \\ Australia. \\ ${ }^{3}$ Adjunct, School of Natural Sciences, Edith Cowan University, Joondalup, Western Australia 6027, \\ Australia. \\ ${ }^{4}$ Present address: Biologic Environmental Survey, East Perth, Western Australia 6004, Australia. \\ Corresponding author: mark.harvey@museum.wa.gov.au
}

\begin{abstract}
The open-holed trapdoor spider genus Aname L. Koch, 1873 is widely distributed throughout Australia, and currently contains 44 named species. Using a combination of morphological and molecular data, we describe five new species from the Wheatbelt, Mid-west and Goldfields regions of Western Australia: $A$. exulans sp. nov., A. lillianae sp. nov., A. mccleeryorum sp. nov., $A$. phillipae sp. nov. and $A$. simoneae sp. nov. The female holotype of Aname armigera Rainbow and Pulleine, 1918 from near Mullewa was examined and found to belong to the genus Proshermacha Simon forming the new combination P. armigera (Rainbow and Pulleine, 1918), comb. nov.
\end{abstract}

KEYWORDS: taxonomy, systematics, molecular phylogenetics

urn:Isid:zoobank.org:pub:98828964-6150-465D-B5AE-1480DA0D454E

\section{INTRODUCTION}

The open-holed trapdoor spider genus Aname L. Koch, 1873 is the most diverse anamid genus with 44 named species recorded from most regions of mainland Australia. The recent detection of a diagnostic morphological feature - the ventral asetose depression on the male pedipalpal tibia — and the inclusion of numerous species of Aname in a comprehensive molecular phylogenetic analysis, confirm that the genus as currently recognised is monophyletic. Although, two recent publications have described 15 new species from Western Australia (Castalanelli et al. 2020; Harvey et al. 2012), there are numerous undescribed species recognised using molecular and morphological data (Castalanelli et al. 2014; Harvey et al. 2018; MSH, JAH, unpublished data).

Although a full revision of the genus is currently beyond our capacity, we here describe five new species from the Wheatbelt, Mid-west and Goldfields regions of Western Australia. Three of these species share substantial morphological similarities with $A$. whitei
Castalanelli, Framenau, Huey and Harvey, 2020, a species from Western Australia recently described in a study focused on the Pilbara region (Castalanelli et al. 2020). During that study, morphologically similar specimens collected from the Goldfields and northern Wheatbelt regions of Western Australia were identified in the Western Australian Museum. Closer study of these specimens, and the acquisition of new sequence data, revealed them to represent three additional species, which can be distinguished from each other and from A. whitei in the divergent morphologies of the pedipalp of adult males, and sometimes also the spermathecae of females. We also describe two new species from the Mid-west region of Western Australia that possess distinct chevron patterns on the abdomen.

Finally, we also studied the female holotype of A. armigera Rainbow and Pulleine, 1918 from near Mullewa, as it occurs within the range of one of the new species. It was found to belong to the genus Proshermacha Simon, 1908. We redescribe and illustrate this species, although we have been unable to match males with the female. 


\section{MATERIALS AND METHODS}

\section{MORPHOLOGY}

The specimens examined in this study are lodged in the Western Australian Museum, Perth (WAM), Queensland Museum, Brisbane (QM) and the Australian Museum, Sydney (AM), and are preserved in $75 \%$ ethanol. Auto-montaged images were taken at different focal planes (c. 20-30 images) with a Leica DFC500 digital camera attached to a Leica MZ16A stereo microscope, using Leica Application Suite (LAS) version 2.5.OR1 software.

Terminology follows Raven (1985a, 1985b) and Castalanelli et al. (2020). The following abbreviations are used: AME: anterior median eyes; ALE: anterior lateral eyes; PLE: posterior lateral eyes; PME: posterior median eyes. Pedipalp and leg measurements and ratios were calculated using the terminology and reference points defined by Castalanelli et al. (2020).

Morphological characters were scored using DELTA 1.4 (CSIRO, Canberra, Australia) (Dallwitz et al. 2010), which was also used to generate a natural language description that was subsequently edited further. The species are treated in alphabetical order.

The map was produced in ArcGIS version 10.1, with the distributions of each species superimposed over the local IBRA bioregions, as defined by Thackway and Cresswell (1995) and Environment Australia (2000). The map layers were accessed from https://www. environment.gov.au/land/nrs/science/ibra (access date 30 January 2020).

\section{MOLECULAR METHODS}

Seven genes were selected for this study, three mitochondrial DNA (mtDNA) genes (cytochrome $c$ oxidase subunit I [COI], 12S rRNA [12S], and 16S rRNA [16S]), and four nuclear DNA (nDNA) genes (18S rRNA [18S], 28S rRNA [28S], Histone H3 [H3] and elongation factor 1-gamma [EF1]). These were the same genes used in Harvey et al. (2018) and all DNA extraction, amplification and sequencing methods follow the methods described therein. Sequences and workflows were managed with the Geneious software package (R9.0.5), using the LIMS Biocode plug-in (http://www. mooreabiocode.org).

As well as the new species described here, representative sequences were selected from 13 previously described species: A. aragog Harvey, Framenau, Wojcieszkek, Rix and Harvey, 2012, $A$. christineae Castalanelli, Framenau, Huey, Hillyer and Harvey, 2020, A. ellenae Harvey, Framenau, Wojcieszkek, Rix and Harvey, 2012, A. grothi Castalanelli, Framenau, Huey, Hillyer and Harvey, 2020, A. kimae Castalanelli, Framenau, Huey, Hillyer and Harvey, 2020, A. lorica Castalanelli, Framenau, Huey, Hillyer and Harvey, 2020, A. mainae Raven, 2000, A. marae Harvey, Framenau, Wojcieszkek, Rix and Harvey, 2012, A. mellosa Harvey, Framenau, Wojcieszkek, Rix and Harvey, 2012, A. pallida L. Koch, 1873, A. sinuata Castalanelli, Framenau, Huey, Hillyer and Harvey,
2020, A. watsoni Castalanelli, Framenau, Huey, Hillyer and Harvey, 2020 and A. whitei Castalanelli, Framenau, Huey, Hillyer and Harvey, 2020 (Table 1). All of these sequences had been previously published in Harvey et al. (2018) and Castalanelli et al. (2020). The tree was rooted on Hesperonatalius maxwelli Castalanelli, Huey, Hillyer and Harvey, 2017, following Harvey et al. (2018), where it was demonstrated that Hesperonatalius was the sister lineage to Aname. Some of the new species described here had also been sequenced in previous publications (Castalanelli et al. 2014; Harvey et al. 2018), and GenBank was used as the source of these sequences. Each gene was aligned using the MAAFT plug-in in Geneious (Katoh et al. 2002), using the default settings. Coding genes were screened for stop codons by translating alignments, and sequences that exhibited stop codons were discarded. Ribosomal gene alignments had ambiguously aligned regions removed using G Blocks (Castresana 2000; Talavera and Castresana 2007), via the web tool (http://molevol.cmima.csic.es/castresana/ Gblocks_server.html), with the settings allowing for gaps and larger blocks. Individual gene trees were built using the RaXML plug-in within Geneious Prime (Stamatakis 2006), with 1,000 bootstraps and using the Generalised time reversible with gamma correction (GTR+gamma) substitution model. The optional partitioning for the concatenated alignment was identified using Partition Finder, version 1.1 (Lanfear et al. 2012), treating each codon independently for coding genes. The optimal partitioning included three partitions; (1) $12 \mathrm{~S}, 16 \mathrm{~S}, C O I$ positions 1 and 2, EF1 position 3, and $H 3$ position 3; (2) $18 \mathrm{~S}, 28 \mathrm{~S}, E F 1$ positions 1 and 2, H3 positions 1 and 2; and (3) COI position 3. A Maximum Likelihood tree was constructed for the concatenated dataset using the RaxML plugin in Geneious Prime, with 1,000 bootstraps and GTR+gamma as the substitution model for all partitions. For the concatenated analysis, Aname lorica, A. watsoni and $A$. whitei sequences were chimeras of sequences published in Castalanelli et al. (2020), as no single specimen of these species was sequenced for every gene. Average interspecific and intraspecific p-distances were calculated for the COI gene using MEGA X (Kumar et al. 2018).

\section{RESULTS AND DISCUSSION}

\section{MOLECULAR DATA}

The concatenated Maximum Likelihood phylogeny included multiple specimens per species for four of the five species described in this study: A. exulans, A. mcleeryorum, A. phillipae and A. simoneae, where available, and reduced the other species to one or two specimens (Figure 1). All of these species were recovered as monophyletic, however, some with low support ( $A$. phillipae, $\mathrm{BS}=69$ and $A$. simoneae $\mathrm{BS}=72$ ). Despite their distributions overlapping (Figure 151), the new species were not each other's closest relatives, with $A$. exulans and $A$. mcleeryorum sister to each other and most closely related to A. mainae from the Eyre Peninsula (South Australia). Aname phillipae, A. simoneae and 
A. whitei formed a closely related clade, which was reflected in their very similar morphology. Overall, the topology presented here should be interpreted with caution as many more unsequenced and undescribed species are known, the inclusion of which could alter the relationships.

The genetic distances recovered here demonstrate the difficulty of identifying a strict species level genetic threshold in Aname. The COI p-distances revealed intraspecific genetic distances as high as $8.98 \%$ in $A$. simoneae, and interspecific distances as low as $7.5 \%$ were recovered between $A$. exulans and $A$. mcleeryorum (Table 2).

\section{MORPHOLOGY}

As noted by Raven (1985a) and Castalanelli et al. (2020), the spermathecae of female Aname contain significant interspecific variation. Indeed, the spermathecae of the closely related $A$. exulans and A. mccleeryorum described below exhibit consistent differences, despite these two species being sister-taxa and only $8 \%$ divergent on average for COI. In contrast, we were unable to differentiate between the females of three closely related species, A. phillipae, A. simoneae (described below) and $A$. whitei, described from the Pilbara (Castalanelli et al. 2020). As A. phillipae and A. simoneae have somewhat overlapping distributions (Figure 151), we were only able to assign females of this species group for which sequence data were available, as this represents the only guaranteed method for identifying females. The Western Australian Museum collection includes several females from the Coolgardie and Murchison IBRA bioregions that could not be identified to either species.

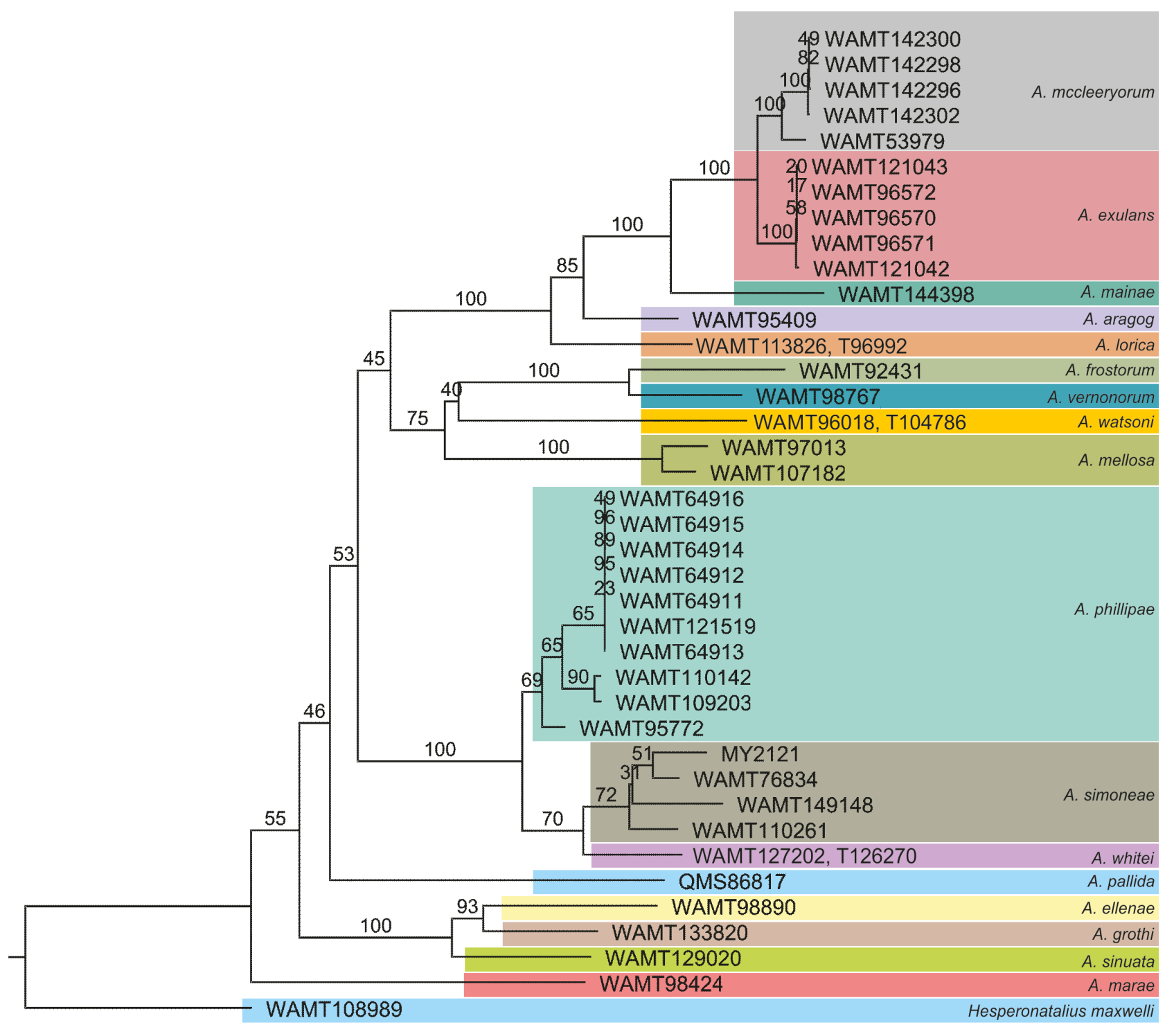

0.1 


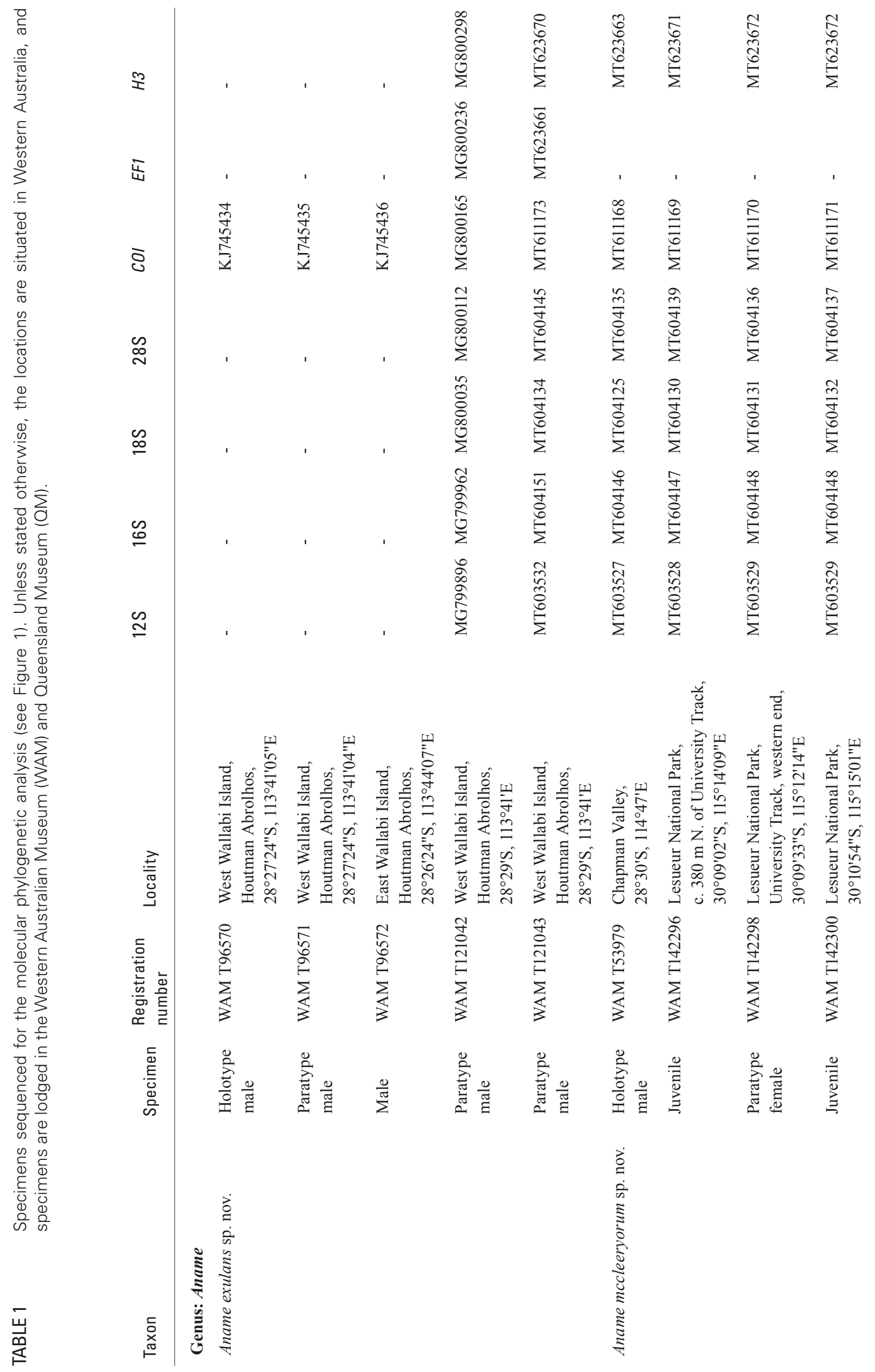




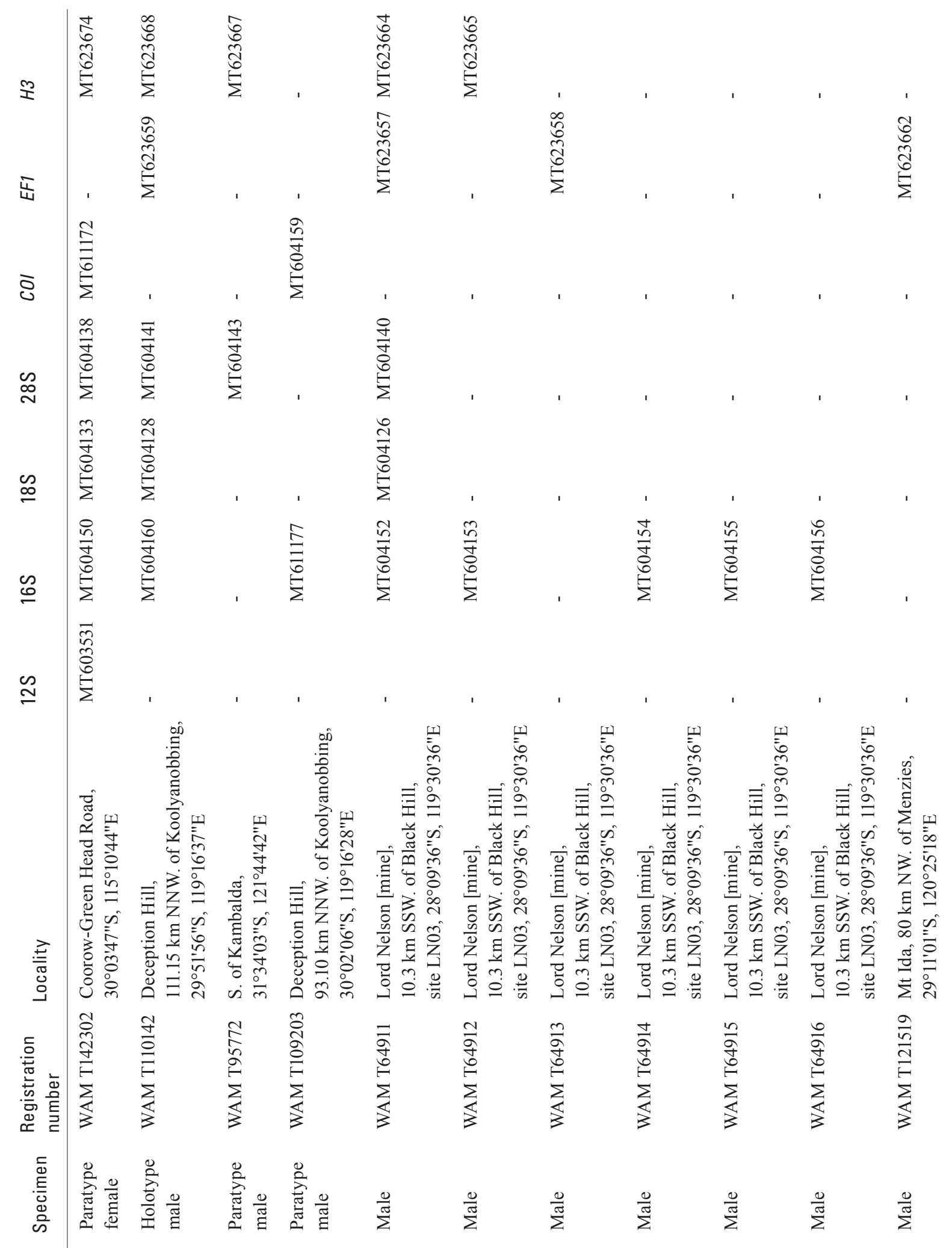




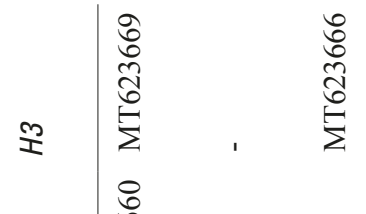

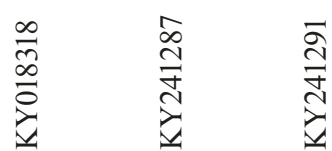

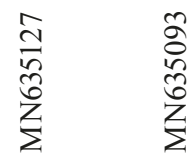

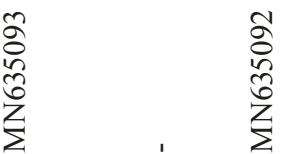
出<smiles>[CH][CH]</smiles>

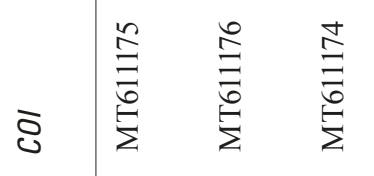
1
0
0
0
0

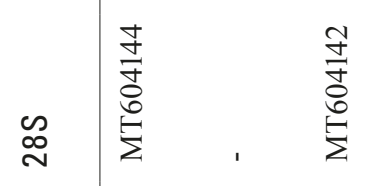

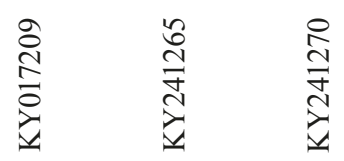

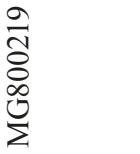

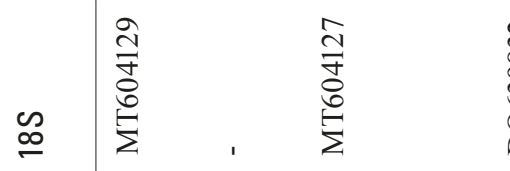

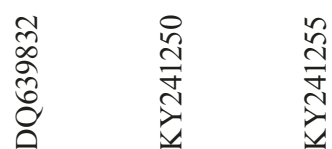
守

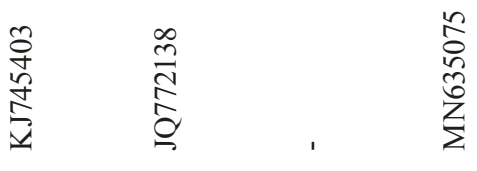
$\begin{array}{ll}\infty & 1 \\ 0 & \hat{0} \\ 0 & 0 \\ 0 & 0 \\ 0 & \vdots \\ \Sigma & \Sigma\end{array}$

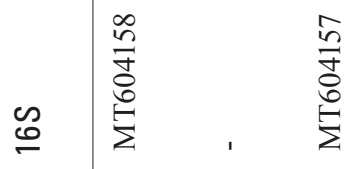

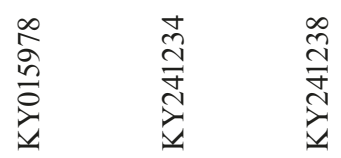

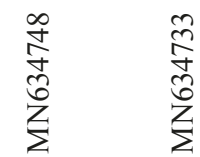
吕

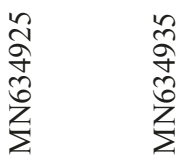

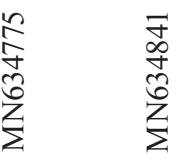

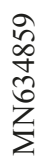

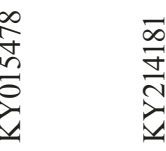

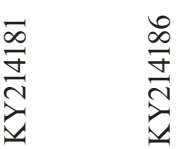

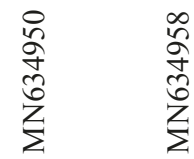

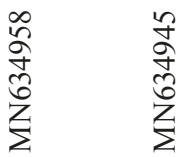

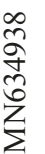
$\stackrel{\simeq}{\simeq}$

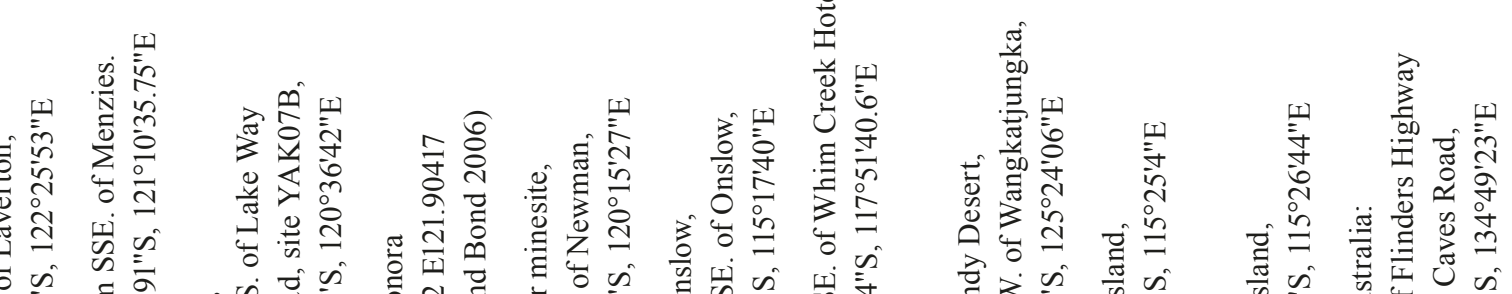

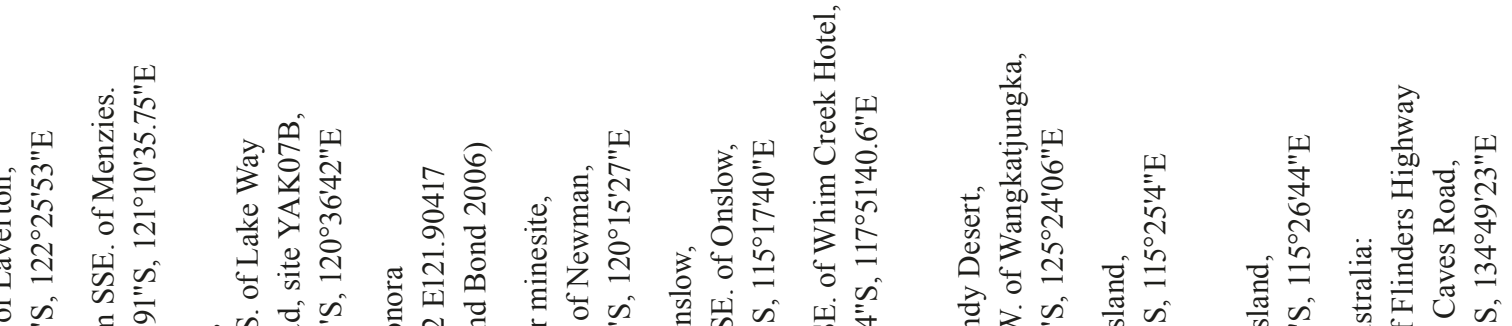

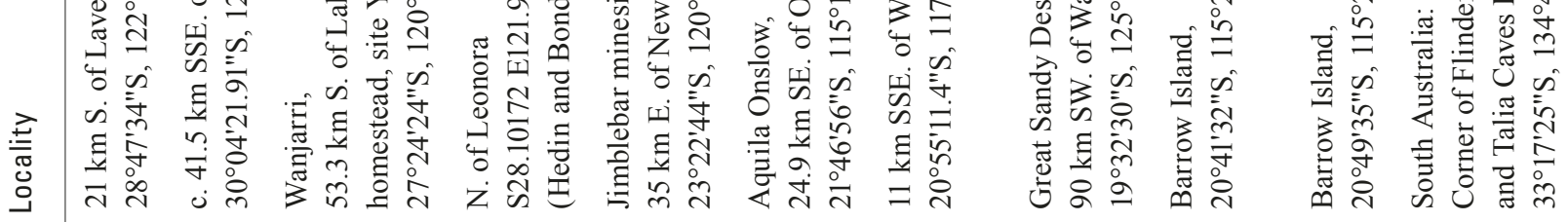

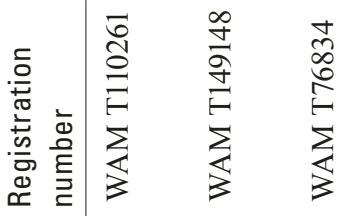

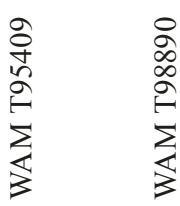

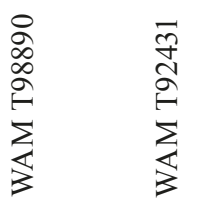

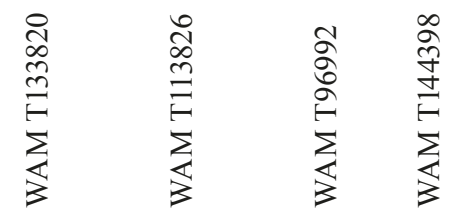
$\overrightarrow{\mathrm{J}}$

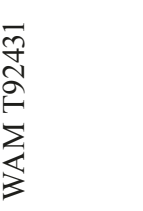

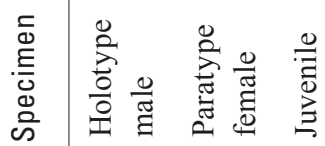

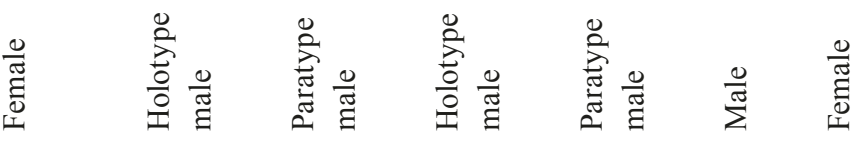
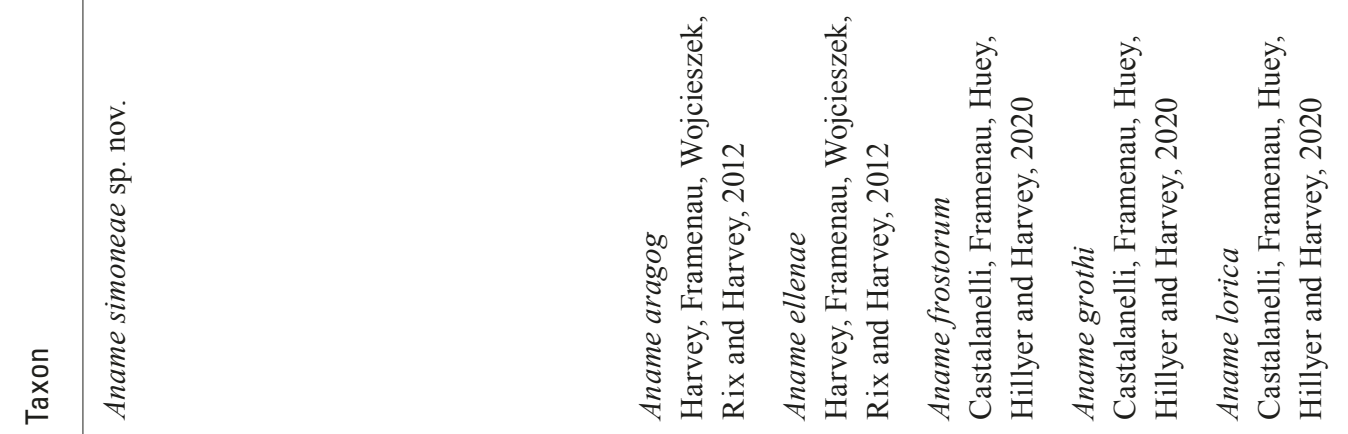

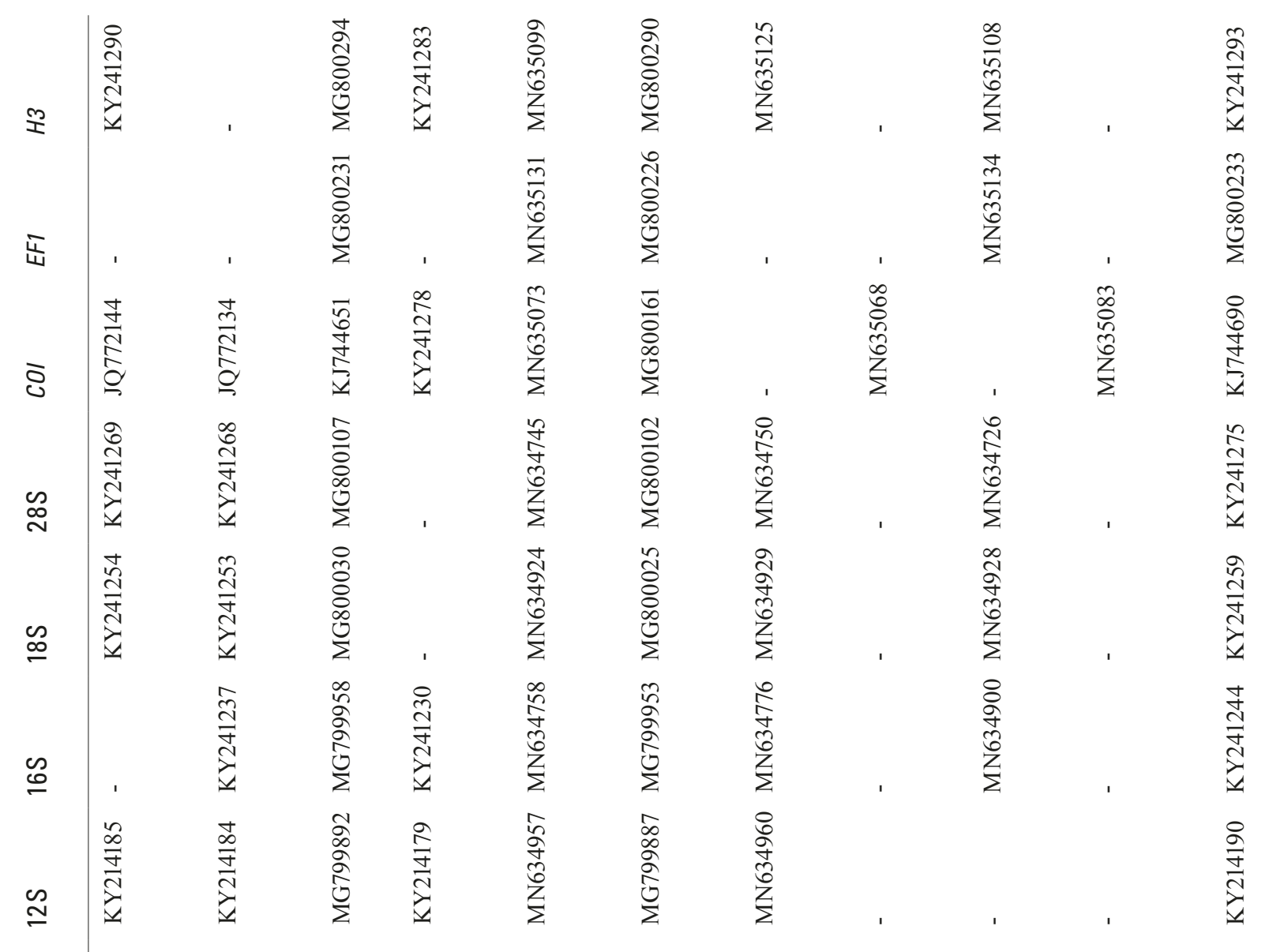

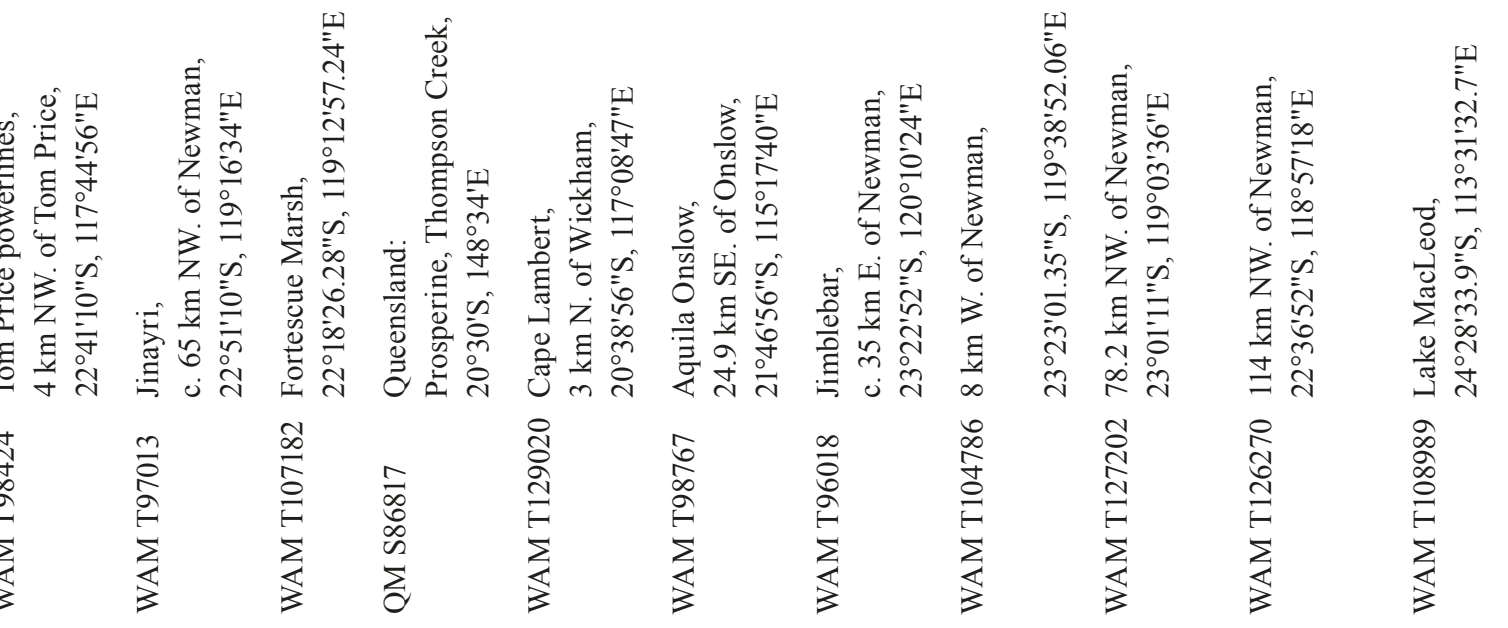

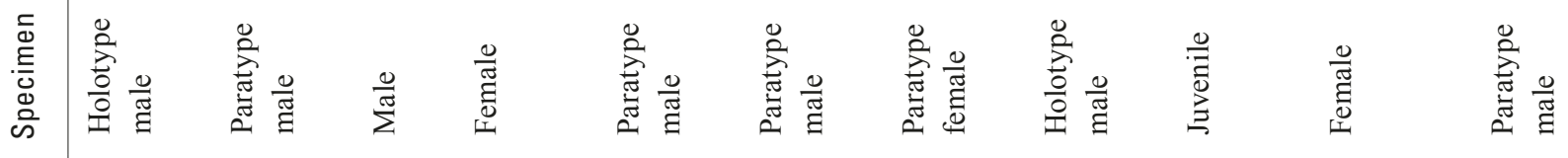

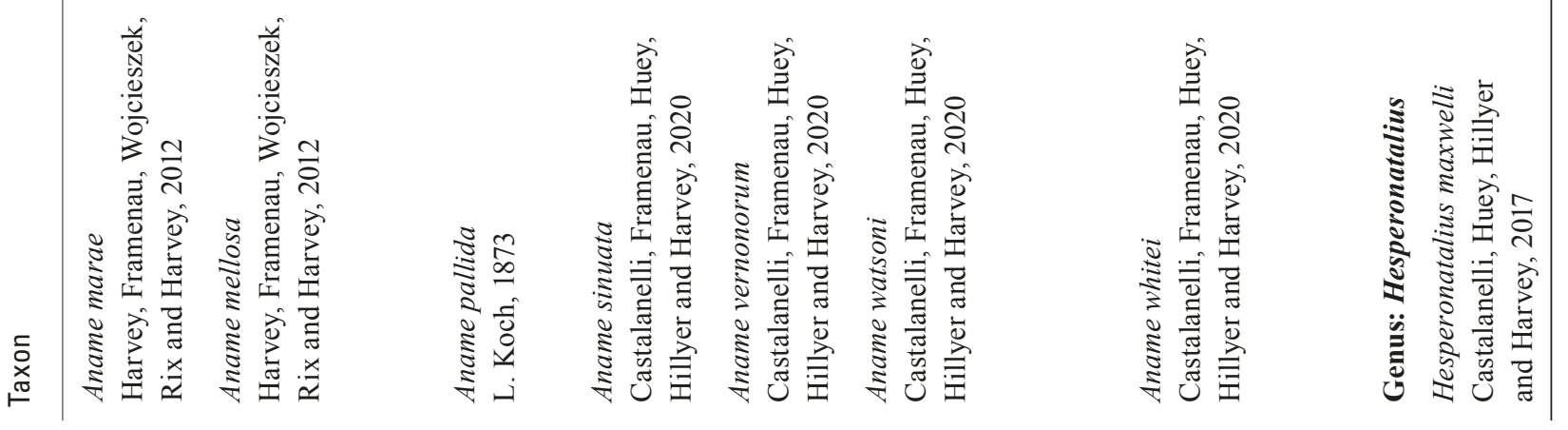




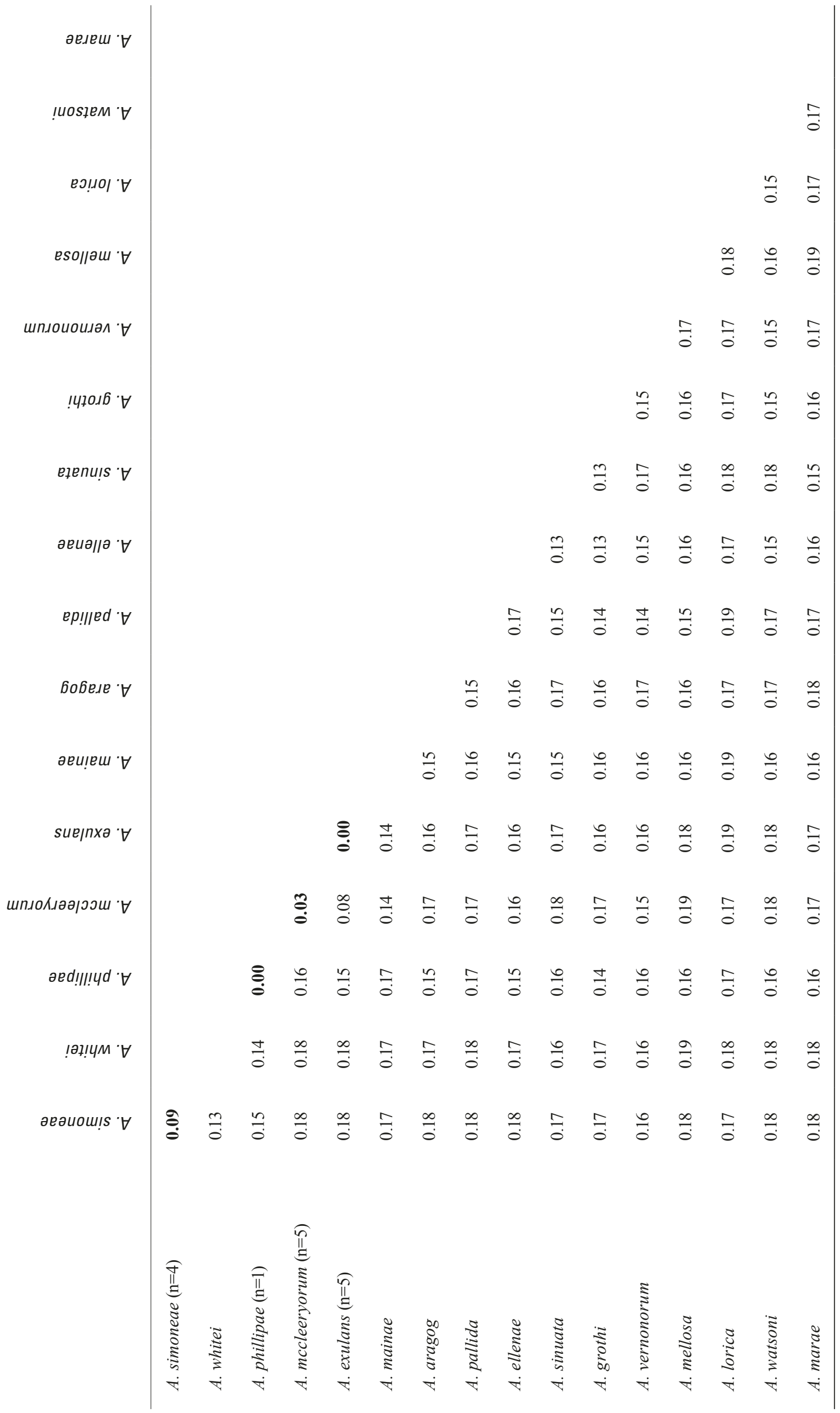




\section{SYSTEMATICS}

\section{Family Anamidae Simon, 1889}

\section{Genus Aname L. Koch, 1873}

Aname L. Koch, 1873: 465. Type species: Aname pallida L. Koch, 1873, by monotypy.

Dekana Hogg, 1902: 138 (synonymised by Raven, 1981: 328). Type species: Dekana diversicolor Hogg, 1902, by original designation.

Sungenia Rainbow and Pulleine, 1918: 162 (synonymised by Raven, 1981: 328). Type species: Chenistonia (Dekana) atra Strand, 1913, by monotypy.

Dolichosternum Rainbow and Pulleine, 1918: 168 (synonymised by Raven, 1981: 328). Type species: Dolichosternum attenuatum Rainbow and Pulleine, 1918 (junior synonym of Ixamatus distinctus Rainbow, 1914), by monotypy.

\section{DIAGNOSIS}

Species of Aname can be distinguished from all other anamids by the presence of prominent asetose ventral depression on the male pedipalpal tibia (Figures 15, 44, $73,104,133)$.

\section{Aname exulans Harvey and Huey, sp. nov.}

Figures 2-30

urn:Isid:zoobank.org:act:E1C159C4-DA92-44D2-8393$92927 B B C 4512$

Aname 'MYG067': Castalanelli 2014: fig. 3.

\section{MATERIAL EXAMINED}

\section{Holotype}

Australia: Western Australia: $\hat{\jmath}$, West Wallabi Island, Houtman Abrolhos, 28²7'24"S, 11341'05"E, 10 January 2008, dry pitfall trap, R. Teale, Z. Hamilton, R.A. How (WAM T96570 ${ }^{\mathrm{DNA}}$ ).

\section{Paratypes}

Australia: Western Australia: 3 , North Island, Houtman Abrolhos, 28 $18^{\prime} \mathrm{S}, 113^{\circ} 36^{\prime} \mathrm{E}, 27$ August 1974, Aquinas Boys College (WAM T10124-10126); 1 q, North Island, Houtman Abrolhos, $28^{\circ} 18^{\prime} \mathrm{S}, 113^{\circ} 36^{\prime} \mathrm{E}$, 3 August 1976, R. Prince (WAM T47464); 2 ô, West Wallabi Island, Houtman Abrolhos, 28²7'24"S, 11341'04"E, 11 January 2008, dry pitfall trap, M.A. Cowan, D. Kamien (WAM T96571 ${ }^{\mathrm{DNA}}$, T96576); 1 ๙े, West Wallabi Island, Houtman Abrolhos, 28²8'04"S, 11341'13"E, 11 February 2012, dry pitfall trap, C.A. Stevenson, M.A. Cowan, P. Spencer, P. Kendrick (WAM T120851); 1 ふै, West Wallabi Island, Houtman Abrolhos, $28^{\circ} 29^{\prime} \mathrm{S}, 113^{\circ} 41^{\prime} \mathrm{E}, 10$ February 2012, C. Stevenson

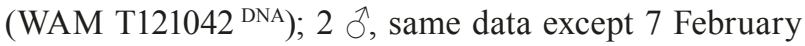
2012 (WAM T121043 ${ }^{\text {DNA }}$, T121044).

\section{Other material}

Australia: Western Australia: 1 ก, 1 juvenile, East Wallabi Island, Houtman Abrolhos, 28²6'24"S, $113^{\circ} 44^{\prime} 07^{\prime \prime E}, 10$ January 2008, dry pitfall trap, R. Teale, Z. Hamilton, R.A. How (WAM T96572 DNA, T96575); 4 ô, 1 juvenile, West Wallabi Island, Houtman Abrolhos, 28²7'24"S, 11341'05"E, 8-11 November 2005, dry pitfall trap, R.A. How, et al. (WAM T77027); 1 juvenile, Houtman Abrolhos, East Wallabi Island, $28^{\circ} 26^{\prime}$ S, $113^{\circ} 43^{\prime} \mathrm{E}, 9$ December 1968, A.R. Main (WAM $\mathrm{T} 147673)$.

\section{DIAGNOSIS}

Aname exulans is easily distinguished from all other named species of Aname by the abdominal colour pattern which comprises a pale background, a dark median stripe and several indistinct chevrons (Figures 9, 27).

Aname exulans most closely resembles $A$. mccleeryorum as the females of both species have distinct chevron patterning on the abdomen. However, the abdomen has a dark median stripe and several indistinct chevrons in A. exulans (Figure 27) but is diffusely grey on a light background in $A$. mccleeryorum (Figures 85, 90). Males of $A$. exulans differ from A. mccleeryorum in the shape of the pedipalp including the longer tibial depression and the longer and straighter embolus (Figures 13-15). Females differ by the coiled and distally bifurcate spermathecal lobes (Figures 29, 30), which are short and slightly curved in $A$. mccleeryorum (Figures 87, 88).

\section{DESCRIPTION}

\section{Male: based on holotype (WAM T96570)}

Colour (in alcohol): Carapace anterior brown-yellow fading to yellow-brown posteriorly; legs brown, some segments with longitudinal pale stripes, tarsi paler; chelicerae uniformly dark red-brown; abdomen dorsally pale yellow-brown with black median stripe and several indistinct chevrons, and ventrally pale yellow-brown.

Cephalothorax: Carapace (Figure 2) $1.26 \times$ longer than broad; with sparse fine setae, silver hairs present, with brown bristles dorsally. Clypeal edge protruding medially. Fovea slightly procurved (Figure 4). Eyes on distinct mound (Figure 3); from above, anterior eye row slightly procurved, posterior eye row slightly recurved; AME about same size as ALE; ALE and AME the largest; PME smallest; eye group length 0.7, width 1.2. Chelicerae with broad dorsal strip of black setae, and two thinner lateral strips of smaller black setae; rastellum absent; promargin of tooth row with 9 teeth, retromargin with 6 teeth. Labium fused to sternum (Figure 7); without cuspules. Maxillae (Figure 7) with 220 cuspules, located on basal third. Sternum (Figure 6): oval, posteriorly pointed; $1.18 \times$ longer than broad; 


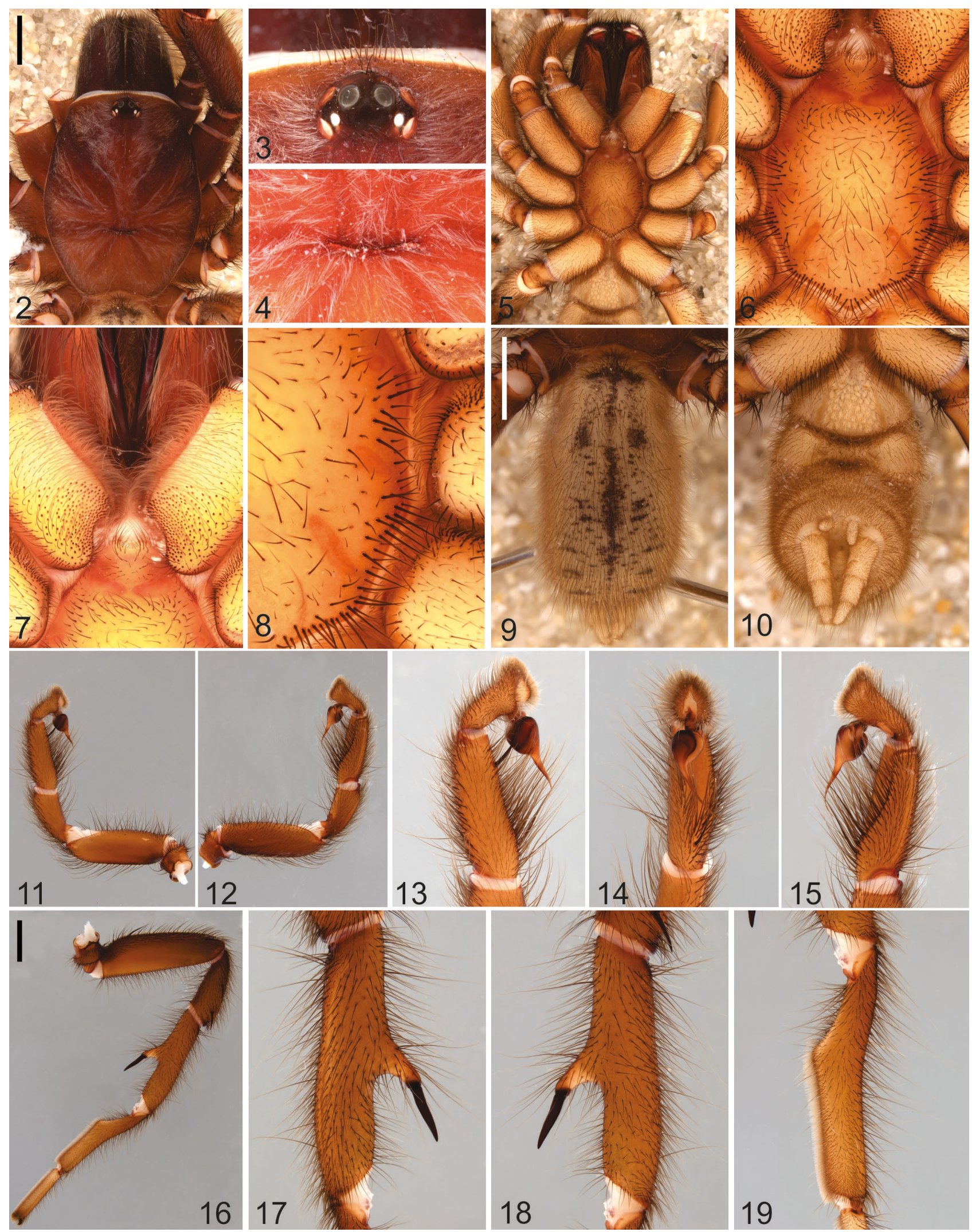

FIGURES 2-19 Aname exulans sp. nov., holotype male (WAM T96570): 2) cephalothorax, dorsal view; 3) ocular region; 4) fovea; 5) cephalothorax, ventral view; 6) sternum, ventral view; 7) maxillae and labium, ventral view; 8) left sigilla, ventral view; 9) abdomen, dorsal view; 10) abdomen, ventral view; 11) left pedipalp, prolateral view; 12) left pedipalp, retrolateral view; 13) left pedipalp, tibia and tarsus, prolateral view; 14) left pedipalp, tibia and tarsus, ventral view; 15) left pedipalp, tibia and tarsus, retrolateral view; 16) left leg I, prolateral view; 17) left leg I, tibia I, retrolateral view; 18) left leg I, tibia I, prolateral view; 19) left leg I, metatarsus I, prolateral view. Scale lines $=2 \mathrm{~mm}$. 
bristles sparsely distributed over entire surface; with 3 pairs of sigilla (Figure 8), each pair increasing in size from anterior to posterior; anterior and median pairs located near edge of sternum; posterior pair elongate.

Pedipalp (Figures 11-15): Tibia cylindrical, narrow; asetose depression present, about the length of embolus; PDL/PTL 0.67. Tarsus short; sparsely setose; bulb ovoid; embolus much longer than bulb, gently curved.

Legs: Coxal cuspules absent (Figure 5). Tibia I with large megaspur (Figures 16-18); TIL/TID 4.38; TIS/TIL 0.52; TISH/TID 0.84; metatarsus incrassate (Figure 19); MIL/MID 5.00; MIPEL/MIL 0.41. Scopula present on all tarsi, metatarsi I and II, and distal half of metatarsi III and IV. Trichobothria: tibia with numerous trichobothria in 2 rows, metatarsi with several trichobothria, tarsi with numerous trichobothria. Claws with 2 rows of teeth; claw tufts absent. Measurements: Leg I: femur 6.2, tibia 6.6, metatarsus 5.5. Leg II: femur 5.6. Leg III: femur 4.6. Leg IV: femur 6.2.

Abdomen (Figures 9, 10): $1.8 \times$ longer than broad, sparsely pilose with long setae on dorsal side. Spinnerets: 2 pairs of spinnerets; PMS unsegmented and separated by about diameter of spinneret; PLS 3-segmented, apical segment elongate, digitiform.

Dimensions ( $\mathrm{mm}$ ): Total body length 20.0; carapace length 8.3, width 6.6; sternum length 3.9 , width 3.3 ; abdomen length 7.5 , width 4.2.

Variation: $\mathrm{N}=10$. Carapace length 7.7-8.7; width 6.47.1; femur I length 6.3-7.0; metatarsus I length 5.0-5.6; femur IV length 6.1-6.8.
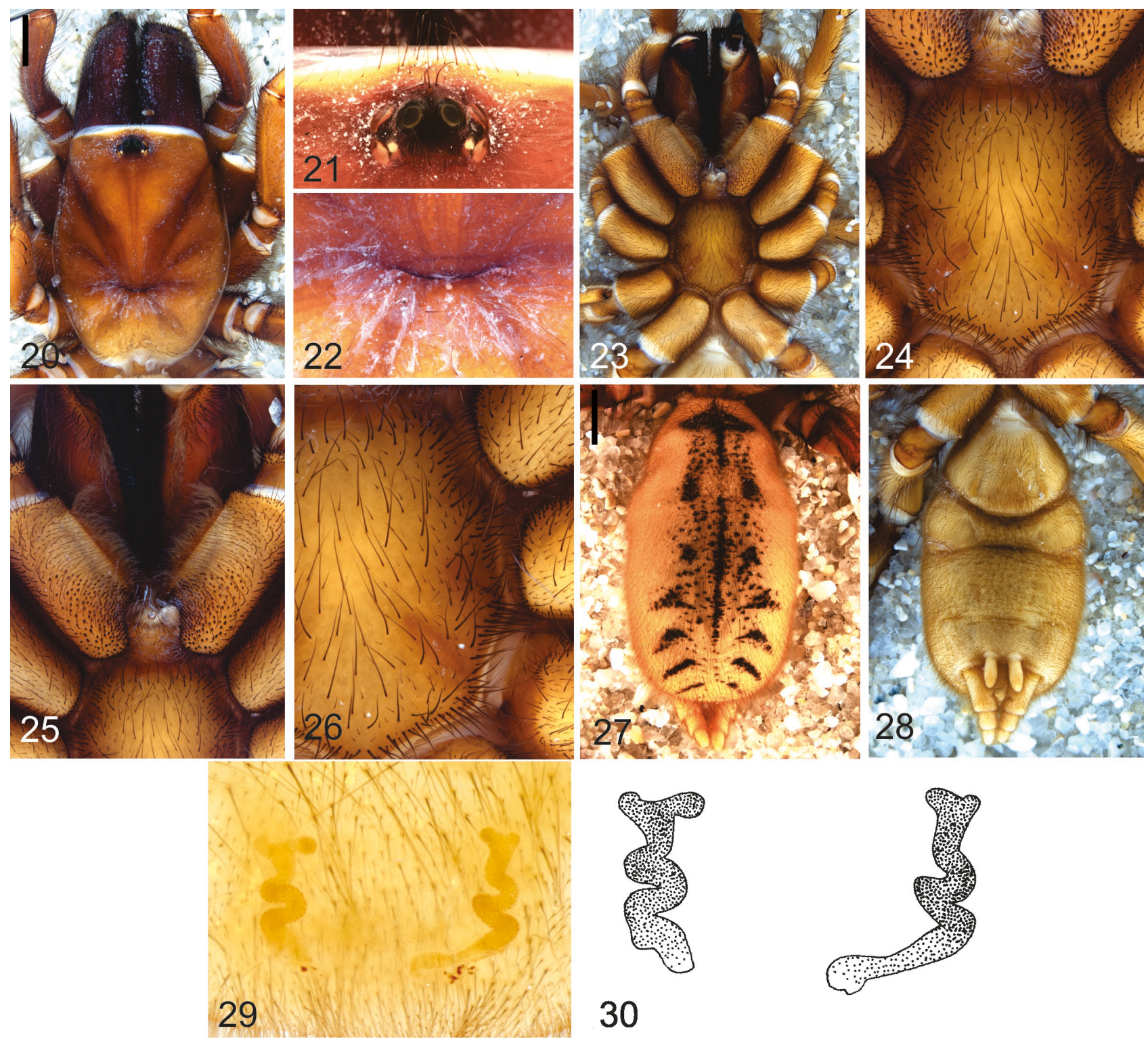

30

FIGURES 20-30 Aname exulans sp. nov., paratype female (WAM T10124): 20) cephalothorax, dorsal view; 21) ocular region; 22) fovea; 23) cephalothorax, ventral view; 24) sternum, ventral view; 25) maxillae and labium, ventral view; 26) left sigilla, ventral view; 27) abdomen, dorsal view; 28) abdomen, ventral view; 29) spermathecae, dorsal view; 30) spermathecae, dorsal view, line drawing. Scale lines $=2 \mathrm{~mm}$. 


\section{Female: based on paratype (WAM T10124).}

Colour (in alcohol): Carapace anterior red-brown fading posteriorly to light brown; legs brown, some segments with longitudinal pale stripes, tarsi paler; chelicerae uniformly dark red-brown; abdomen dorsally pale yellow-brown with black median stripe and several distinct chevrons, and ventrally pale yellow-brown.

Cephalothorax: Carapace (Figure 20) $1.18 \times$ longer than broad; with sparse fine setae, silver hairs absent, with brown bristles dorsally. Clypeal edge protruding medially. Fovea slightly procurved (Figure 22). Eyes on distinct mound (Figure 21); from above, anterior eye row slightly procurved, posterior eye row slightly recurved; AME about same size as ALE; ALE and AME the largest; PME smallest; eye group length 0.7, width 1.3. Chelicerae with broad dorsal strip of black setae, and two thinner lateral strips of smaller black setae; rastellum absent; promargin of tooth row with 9 teeth, retromargin with 5 teeth. Labium fused to sternum (Figure 25); without cuspules. Maxillae (Figure 25) with 225 cuspules; located on basal half. Sternum (Figure 24): oval, posteriorly pointed; $1.18 \times$ longer than broad; bristles sparsely distributed over entire surface; with 3 pairs of sigilla (Figure 26), each pair increasing in size from anterior to posterior; anterior and median pairs located near edge of sternum; posterior pair elongate.

Pedipalp: Tarsus densely setose.

Legs: Coxal cuspules absent (Figure 23). Scopula present on all tarsi, present on metatarsi I and II, present on distal half of metatarsi III and IV. Trichobothria: tibia with numerous trichobothria in 2 rows, metatarsi with several trichobothria, tarsi with numerous trichobothria. Claws with 2 rows of teeth; claw tufts absent. Measurements: Leg II: femur 6.0. Leg III: femur 5.5. Leg IV: femur 6.6.

Abdomen (Figures 27, 28): $1.7 \times$ longer than broad, sparsely pilose with long setae on dorsal side. Spinnerets: 2 pairs of spinnerets; PMS unsegmented and separated by about diameter of spinneret; PLS 3-segmented, apical segment elongate, digitiform.

Genitalia (Figures 29, 30): 1 pair of spermathecae, each coiled and distally bifurcate.

Dimensions (mm): Total body length 25.8; carapace length 8.7, width 7.4; sternum length 4.5 , width 3.8 ; abdomen length 11.1, width 6.4.

Variation: $\mathrm{N}=3$. Carapace length 10.4-10.6; width 8.5-8.9; femur I length 7.5-7.6; femur IV length 7.3-8.1.

\section{DISTRIBUTION}

Aname exulans has only been found on three islands of the Houtman Abrolhos Group (North Island, West Wallabi Island and East Wallabi Island), which are located c. $60 \mathrm{~km}$ from the Western Australian coast in the Geraldton Sandplains IBRA bioregion of Western Australia (Figure 151).

\section{REMARKS}

Despite examining many collections of Aname specimens from mainland Australia, we have not detected specimens of $A$. exulans from anywhere other than the Houtman Abrolhos (Figure 151) where it is likely to be endemic. The occurrence of a species of Aname that is apparently endemic to the Abrolhos Islands is somewhat remarkable, given that the islands have been connected to mainland Australia as recently as 6,500 years ago (Collins et al. 2006).

\section{SEQUENCE DATA}

Intraspecific genetic divergence for this species was low, reaching only $0.06 \%$ at $C O I$. It was also very closely related to its morphologically distinct sister species, A. mcleeryorum (7.5\%), found on the mainland adjacent to the islands inhabited by $A$. exulans (Figure 151). Sequence data for a specimen of this species was supplied by Castalanelli et al. (2014) using the code Aname 'MYG067'.

\section{ETYMOLOGY}

The species epithet refers to the presence of this species on offshore islands (exul, Latin, a banished person, exile) (Brown 1956).

\section{Aname lillianae Harvey and Huey, sp. nov.}

Figures 31-59

urn:Isid:zoobank.org:act:F5610B98-5EB0-4E0A-931CCC26A2F2E1EA

\section{MATERIAL EXAMINED}

\section{Holotype}

Australia: Western Australia: ${ }^{\lambda}$, Pallottine Mission, near Tardun, $28^{\circ} 47^{\prime} \mathrm{S}, 115^{\circ} 51^{\prime} \mathrm{E}$, collection date unknown, donated February 1990, W.H. van Veen (WAM T20639, formerly 90/609).

\section{Paratypes}

Australia: Western Australia: 1 ô, Tutanning Nature Reserve, c. $32^{\circ} 32^{\prime} \mathrm{S}, 117^{\circ} 19^{\prime} \mathrm{E}, 29$ January 1987, G.T. Smith et al. (WAM T146038); 1 ㅇ, Tutanning Nature Reserve, c. $32^{\circ} 32^{\prime} \mathrm{S}, 117^{\circ} 19^{\prime} \mathrm{E}, 20$ October 1987, G.T. Smith et al. (WAM T146039).

\section{Other material}

Australia: Western Australia: 2 $\hat{\text {, }}$, Blue Hill Range, 290' $38^{\prime \prime}$ S, $116^{\circ} 53^{\prime} 40 " \mathrm{E}, 13-16$ February 2004, dry pitfall, ironstone ridge in mulga/eucalypt woodland, M.

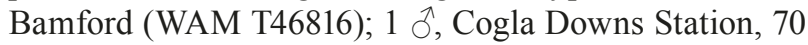
miles NNW. of Sandstone, $27^{\circ} 26^{\prime} \mathrm{S}, 118^{\circ} 56^{\prime} \mathrm{E}$, January 1982, A.R. Humphries (WAM T18133, formerly 88/110); $1 \mathrm{O}^{\top}$, Coolgardie, $30^{\circ} 57^{\prime} \mathrm{S}, 121^{\circ} 10^{\prime} \mathrm{E}, 26$ February 1993 , donated via Department of Conservation and Land Management, Kalgoorlie (WAM T27271, formerly 93/587); 1 ô, Durokoppin Nature Reserve, 31 ${ }^{\circ} 24^{\prime} 37^{\prime \prime S}$, 117'45'37"E, 6 August 1987, pitfall trap, G.R. Friend (WAM T142375); 1 ô, Marloo Station, c. 20 miles W. of Yalgoo, $28^{\circ} 19^{\prime} \mathrm{S}, 116^{\circ} 11^{\prime} \mathrm{E}, 31$ January 1968, A.M. Douglas, L.E. Koch (WAM T29852, formerly 94/263); 

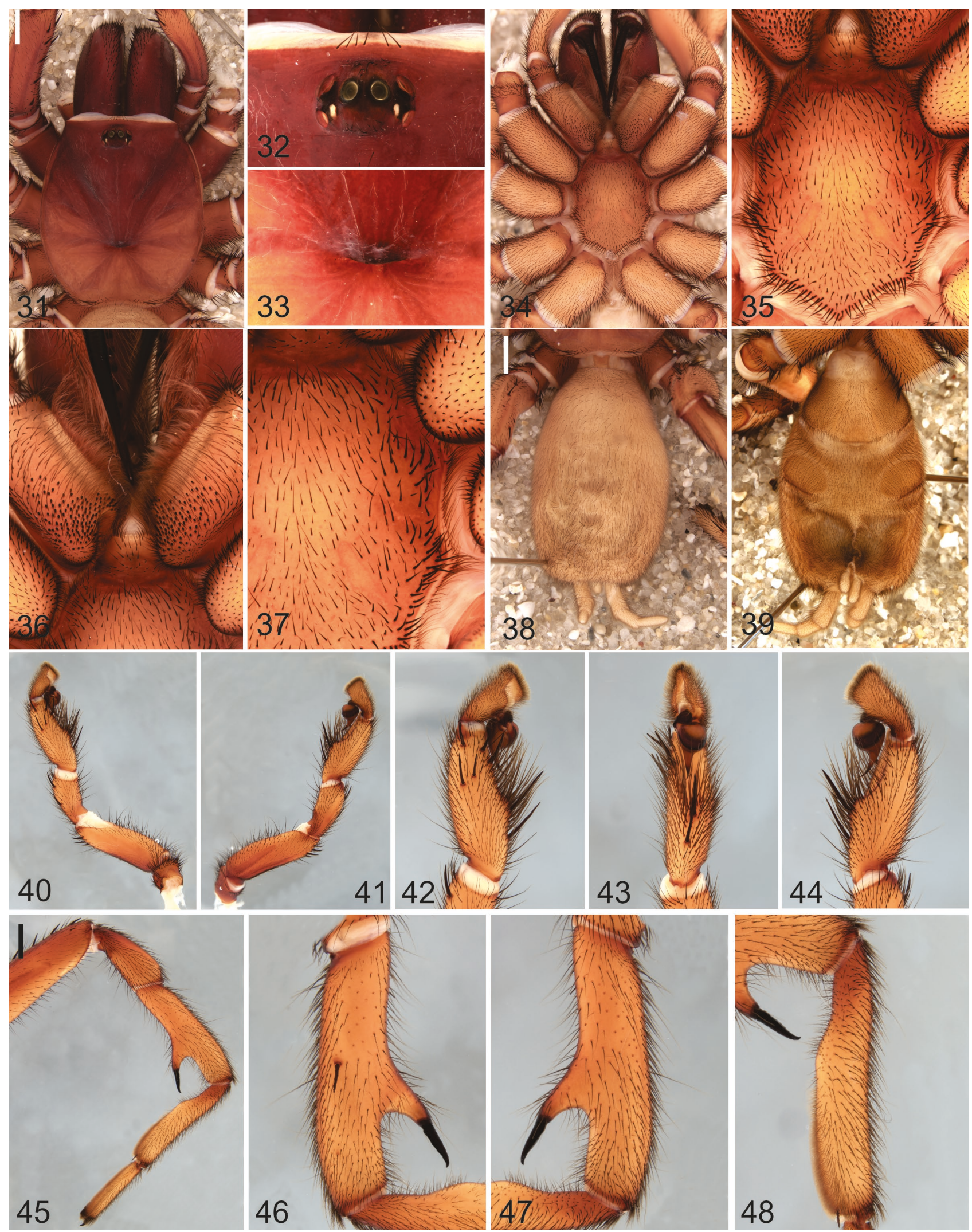

FIGURES 31-48

Aname lillianae sp. nov., holotype male (WAM T20639): 31) cephalothorax, dorsal view; 32) ocular region; 33) fovea; 34) cephalothorax, ventral view; 35) sternum, ventral view; 36) maxillae and labium, ventral view; 37) left sigilla, ventral view; 38) abdomen, dorsal view; 39) abdomen, ventral view; 40) left pedipalp, prolateral view; 41) left pedipalp, retrolateral view; 42) left pedipalp, tibia and tarsus, prolateral view; 43) left pedipalp, tibia and tarsus, ventral view; 44) left pedipalp, tibia and tarsus, retrolateral view; 45) left leg I, prolateral view; 46) left leg I, tibia I, retrolateral view; 47) left leg I, tibia I, prolateral view; 48) left leg I, metatarsus I, prolateral view. Scale lines $=2 \mathrm{~mm}$. 
1 o, McClellands [= McLennans], c. $10 \mathrm{~km} \mathrm{NW}$. of Kellerberrin, 3134'40"S, 117³7'58"E, 10 March 1987, G.T. Smith et al. (WAM T146035); 1 \%, Merredin, $31^{\circ} 29^{\prime} \mathrm{S}, 118^{\circ} 16^{\prime} \mathrm{E}, 15$ January 1930 , collector unknown (WAM T2213, formerly 30/51); 1 त, Ryans, c. $29 \mathrm{~km}$ NE. of Kellerberrin, $31^{\circ} 23^{\prime} \mathrm{S}, 117^{\circ} 51^{\prime} \mathrm{E}, 27$ January 1987 , G.T. Smith et al. (WAM T146036).

\section{DIAGNOSIS}

Aname lillianae most closely resembles $A$. whitei, $A$. simoneae and $A$. phillipae as adults of all three species are large and rather pale, with extremely thin third sigilla (Figures 37, 55). Males differ from A. whitei, A. simoneae and A. phillipae by the tapering, slender embolus (Figure 44), whereas the embolus of $A$. whitei and $A$. simoneae is thickened and flattened, and the embolus of $A$. phillipae has a small distinct hook. The female genitalia (Figures 58, 59) differ from all other species of Aname in the possession of 2 pairs of spermathecae, with the median pair slightly coiled, and the lateral pair straight and with a slightly bulbous head.

\section{DESCRIPTION}

\section{Male: based on holotype (WAM T20639)}

Colour (in alcohol): Carapace anterior red-brown fading posteriorly to light brown; legs yellow-brown with red-brown distal and basal portions; chelicerae deep red-brown; abdomen dorsally pale creamy-yellow, and ventrally pale creamy-yellow.
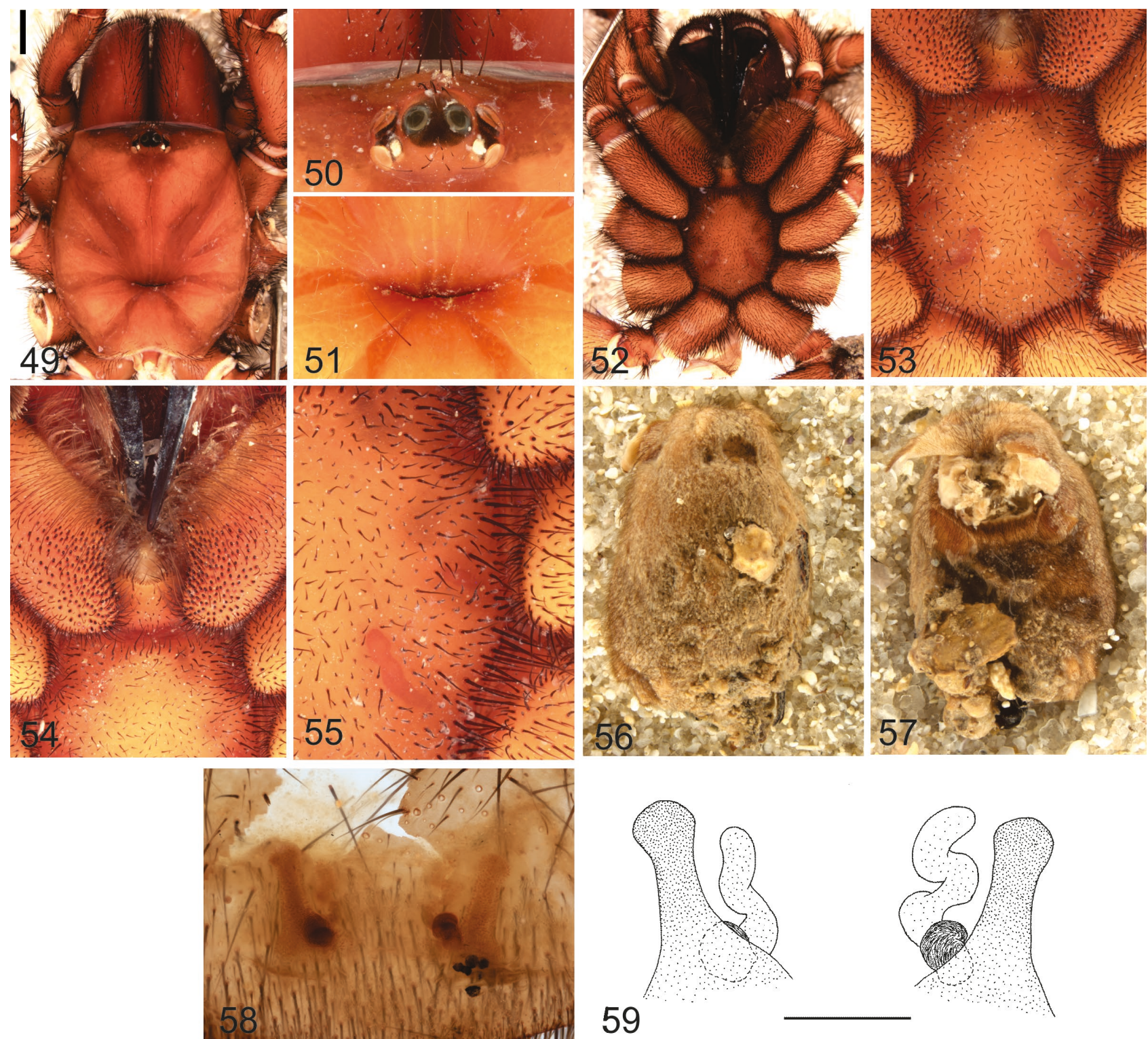

FIGURES 49-59 Aname lillianae sp. nov., paratype female (WAM T146039): 49) cephalothorax, dorsal view; 50) ocular region; 51) fovea; 52) cephalothorax, ventral view; 53) sternum, ventral view; 54) maxillae and labium, ventral view; 55) left sigilla, ventral view; 56) abdomen, dorsal view (damaged); 57) abdomen, ventral view (damaged); 58) spermathecae, dorsal view; 59) spermathecae, dorsal view, line drawing. Scale lines $=2 \mathrm{~mm}$. 
Cephalothorax: Carapace (Figure 31) $1.09 \times$ longer than broad; with sparse fine setae, silver hairs present, with brown bristles dorsally. Clypeal edge protruding medially. Fovea slightly procurved (Figure 33). Eyes on distinct mound (Figure 32); from above, anterior eye row slightly procurved, posterior eye row slightly recurved; PME same size as AME; ALE and AME the largest; PME smallest; eye group length 1.03, width 1.92. Chelicerae with broad dorsal strip of black setae, and two thinner lateral strips of smaller black setae; rastellum absent; promargin of tooth row with 12 teeth, retromargin with 2 teeth. Labium fused to sternum (Figure 36); without cuspules. Maxillae (Figure 36) with 117 cuspules; located on basal third. Sternum (Figure 35): oval, posteriorly pointed; $1.12 \times$ longer than broad; bristles over entire surface; with 3 pairs of sigilla (Figure 37), each pair increasing in size from anterior to posterior; posterior pair elongate and slightly curved; anterior pair located near edge of sternum.

Pedipalp (Figures 40-44): Tibia cylindrical, narrow; asetose depression present, about the length of embolus; PDL/PTL 0.50; densely setose; bulb globular; embolus about same length as bulb, gently curved.

Legs: Coxal cuspules absent (Figure 34). Tibia I with large megaspur (Figures 45-47); TIL/TID 4.23; TIS/TIL 0.66; TISH/TID 0.80; metatarsus slightly incrassate (Figure 48); MIL/MID 5.12; MIPEL/MIL 0.40 . Scopula present on all tarsi, and metatarsi I and II. Trichobothria: tibia with numerous trichobothria in 2 rows, metatarsi with several trichobothria, tarsi with numerous trichobothria. Claws with 2 rows of teeth; claw tufts absent. Measurements: Leg I: femur 9.5, tibia 8.0, metatarsus 7.3. Leg II: femur 9.3. Leg III: femur 8.5. Leg IV: femur 10.4.

Abdomen (Figures 38, 39): $1.5 \times$ longer than broad, sparsely pilose with long setae on dorsal side. Spinnerets: 2 pairs of spinnerets; PMS unsegmented and separated by about diameter of spinneret; PLS 3segmented, apical segment elongate, digitiform.

Dimensions ( $\mathrm{mm}$ ): Total body length 24.5; carapace length 10.9, width 10.0; sternum length 5.7, width 5.0; abdomen length 11.6, width 8.0.

Variation: $\mathrm{N}=10$; carapace length 9.8-12.5; width 8.9-10.8; femur I length 8.4-10.2; metatarsus I length 6.5-7.7; femur IV length 8.9-10.9.

\section{Female: based on paratype (WAM T146039).}

Colour (in alcohol): Carapace uniformly red-brown; legs uniformly red-brown; chelicerae uniformly dark red-brown; abdomen dorsally pale creamy-yellow, and ventrally pale creamy-yellow.

Cephalothorax: Carapace (Figure 49) $1.19 \times$ longer than broad; with sparse fine setae, silver hairs absent, with brown bristles dorsally. Clypeal edge protruding medially. Fovea slightly procurved (Figure 51). Eyes (Figure 50) on distinct mound; from above, anterior eye row nearly straight, posterior eye row slightly recurved;
AME about same size as PME; ALE and AME the largest; PME smallest; eye group length 1.0, width 1.88. Chelicerae with short black setae, sparsely distributed, 1 well-defined prolateral strip dense, long, and brown or black setae; rastellum absent; promargin of tooth row with 10, retromargin with 4 . Labium fused to sternum (Figure 54); without cuspules. Maxillae (Figure 54) with c. 125 cuspules; located on basal third. Sternum (Figure 53): oval, posteriorly pointed; $1.1 \times$ longer than broad; bristles over entire surface; with 3 pairs of sigilla (Figure 55), each pair increasing in size from anterior to posterior; posterior pair elongate and slightly curved; anterior pair located near edge of sternum.

\section{Pedipalp: Tarsus with thick scopula.}

Legs: Coxal cuspules absent (Figure 52). Scopula present on all tarsi, and metatarsi I and II. Trichobothria: tibia with numerous trichobothria in 2 rows, metatarsi with several trichobothria, tarsi with numerous trichobothria. Claws with 2 rows of teeth; claw tufts absent. Measurements: Leg I: femur 8.5. Leg II: femur 8.0. Leg III: Absent. Leg IV: femur 9.0.

Abdomen (Figures 56, 57): densely pilose. Spinnerets: 2 pairs of spinnerets; PMS unsegmented and separated by about diameter of spinneret; PLS 3-segmented, apical segment elongate, digitiform.

Genitalia (Figures 58, 59): 2 pairs of spermathecae, median pair slightly coiled, lateral pair straight and with slightly bulbous head.

Dimensions ( $\mathrm{mm}$ ): Total body length ? (damaged); carapace length 11.2, width 9.4; sternum length 5.6, width 5.1; abdomen ? (damaged).

\section{DISTRIBUTION}

Aname lillianae is widely distributed throughout the northern wheatbelt of Western Australia, including the following IBRA regions: Avon Wheatbelt, Coolgardie, Murchison, and Yalgoo (Figure 151).

\section{REMARKS}

Most males were collected during the summer months of January to March, although one was collected in August. The sole female was collected from Tutanning Nature Reserve and is associated with this species based on the occurrence of a male from the same location and their overall similarity, especially in its large size and yellow-brown colouration which is a relatively uncommon pair of characteristics for Aname species in this region.

This species was formerly known by the WAM identification code Aname 'MYG522'.

\section{SEQUENCE DATA}

Molecular data are not available for this species.

\section{ETYMOLOGY}

This species is named for Lillian Huey, daughter of Joel A. Huey. 
Aname mccleeryorum

Harvey and Huey, sp. nov.

Figures $60-90$

urn:Isid:zoobank.org:act:E9053B92-0DAD-400C-B9655E3FA213FCB8

\section{MATERIAL EXAMINED}

\section{Holotype}

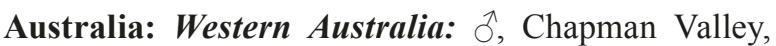
$28^{\circ} 30^{\prime} \mathrm{S}, 114^{\circ} 47^{\prime} \mathrm{E}, 1$ April 2003, J. Webb (WAM T53979 DNA).

\section{Paratypes}

Australia: Western Australia: 1 के, Geraldton, David Road, 284'S, 114³9'E, 24 May 1995, R. McAlpine (WAM T32568); 1 , Lesueur National Park, University Track, western end, $30^{\circ} 09^{\prime} 33^{\prime \prime} \mathrm{S}, 115^{\circ} 12^{\prime} 14^{\prime \prime} \mathrm{E}, 239 \mathrm{~m}$, 6 December 2016, wandoo woodland, J.A. Huey, M. Hillyer, J. Carvajal, M.S. Harvey (WAM T142298 ${ }^{\mathrm{DNA}}$ ); 1 ㅇ, Coorow-Green Head Road, $30^{\circ} 03^{\prime} 47^{\prime \prime S}, 115^{\circ} 10^{\prime} 44^{\prime \prime E}$, 122 m, 7 December 2016, wandoo woodland, J. Carvajal, J.A. Huey, M. Hillyer, M.S. Harvey (WAM T142302 DNA).

\section{Other material}

Australia: Western Australia: 2 ㅇ, 2 penultimate

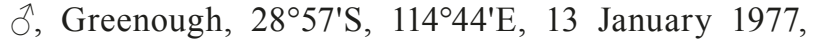
C.L. Duncan (WAM T27543-27546); 1 juvenile, Lesueur National Park, c. $380 \mathrm{~m}$ N. of University Track, 3009'02"S, 115 14'09"E, 209 m, 5 December 2016, kwongan heath on sand, M.S. Harvey, J.A. Huey, M. Hillyer, J. Carvajal (WAM T142296 ${ }^{\text {DNA }}$ ); 1 juvenile, Lesueur National Park, 300'54"S, $115^{\circ} 15^{\prime} 01 " \mathrm{E}, 179 \mathrm{~m}$, 6 December 2016, wandoo woodland, J. Carvajal, J.A. Huey, M. Hillyer, M.S. Harvey (WAM T142300 ${ }^{\mathrm{DNA}}$ ); 1 q (died in captivity, fragments only), same data (WAM T142299); 1 을, Oakajee, 2834'19.45"S, 114³6'03.49"E, 1 August 2006, M. Davis, J. Clark (WAM T104747); 3 응, Oakajee, $28^{\circ} 34^{\prime} 24.78^{\prime \prime S}, 114^{\circ} 36^{\prime} 20.64^{\prime \prime E}, 1-5$ August 2006, M. Davis, J. Clark (WAM T107695, T129049, T129050); 1 juvenile, Oakajee, 28³4'10.00"S, $114^{\circ} 36^{\prime} 15.00^{\prime \prime E}, 1-5$ August 2006, M. Davis, J. Clark (WAM T107689).

\section{DIAGNOSIS}

Aname mccleeryorum most closely resembles $A$. exulans as the females have distinct chevron patterning on the abdomen, which is diffusely grey on a light background (Figures 85, 90) but with a dark median stripe and several indistinct chevrons in $A$. exulans (Figure 27). Males of A. mccleeryorum differ from $A$. exulans in the shape of the pedipalp including the shorter tibial depression and the shorter and slightly curved embolus (Figures 71-73). Females differ by short, slightly curved spermathecal lobes (Figures 87, 88 ) which are coiled and distally bifurcate in $A$. exulans (Figures 29-30).

\section{DESCRIPTION}

\section{Male: based on holotype (WAM T53979)}

Colour (in alcohol): Carapace deep brown; legs brown, some segments with longitudinal pale stripes, tarsi paler; chelicerae deep red-brown; abdomen dorsally grey-brown, and ventrally pale yellow-brown.

Cephalothorax: Carapace (Figure 60) $1.28 \times$ longer than broad, pilose, silver hairs present, with brown bristles dorsally. Clypeal edge protruding medially. Fovea slightly procurved (Figure 62). Eyes on distinct mound (Figure 61); from above, anterior eye row straight, posterior eye row slightly recurved; AME about same size as ALE; ALE and AME the largest; PME smallest; eye group length 0.9, width 1.5 . Chelicerae with short black setae, sparsely distributed, 1 well-defined prolateral strip of dense, long, and brown or black setae; rastellum absent; promargin of tooth row with 10 teeth, retromargin with 6 teeth. Labium fused to sternum (Figure 65); without cuspules. Maxillae (Figure 65 ) with 204 cuspules; located on basal third. Sternum (Figure 64): oval, posteriorly pointed; $1.23 \times$ longer than broad; bristles over entire surface; with 3 pairs of sigilla (Figure 66), each pair increasing in size from anterior to posterior; posterior pair elongate and slightly curved; anterior and median pairs located near edge of sternum.

Pedipalp (Figures 69-73): Tibia cylindrical, narrow; asetose depression present, about the length of embolus; PDL/PTL 0.44. Tarsus short, broadest distally; densely setose; bulb globular; embolus short, not much longer than bulb, gently curved.

Legs: Coxal cuspules absent (Figure 63). Tibia I with large megaspur (Figures 74-76); TIL/TID 4.13; TIS/ TIL 0.55; TISH/TID 0.79; metatarsus incrassate (Figure 77); MIL/MID 4.68; MIPEL/MIL 0.42. Scopula present on all tarsi, present on metatarsi I and II, present on distal half of metatarsi III and IV. Trichobothria: tibia with numerous trichobothria in 2 rows, metatarsi with several trichobothria, tarsi with numerous trichobothria. Claws with 2 rows of teeth; claw tufts absent. Measurements: Leg I: femur 8.5, tibia 8.8, metatarsus 7.2. Leg II: femur 8.0. Leg III: femur 5.8. Leg IV: femur 8.4 .

Abdomen (Figures 67, 68): $1.9 \times$ longer than broad, densely pilose. Spinnerets: 2 pairs of spinnerets; PMS unsegmented and separated by about diameter of spinneret; PLS 3-segmented, apical segment elongate, digitiform.

Dimensions (mm): Total body length 24.7; carapace length 10.9 , width 8.5 ; sternum length 5.3 , width 4.3 ; abdomen length 8.8 , width 4.7 .

Variation: $\mathrm{N}=1$. Carapace length 11.1 ; width 8.5 ; femur I length 8.8; metatarsus I length 6.9; femur IV length 8.6. 

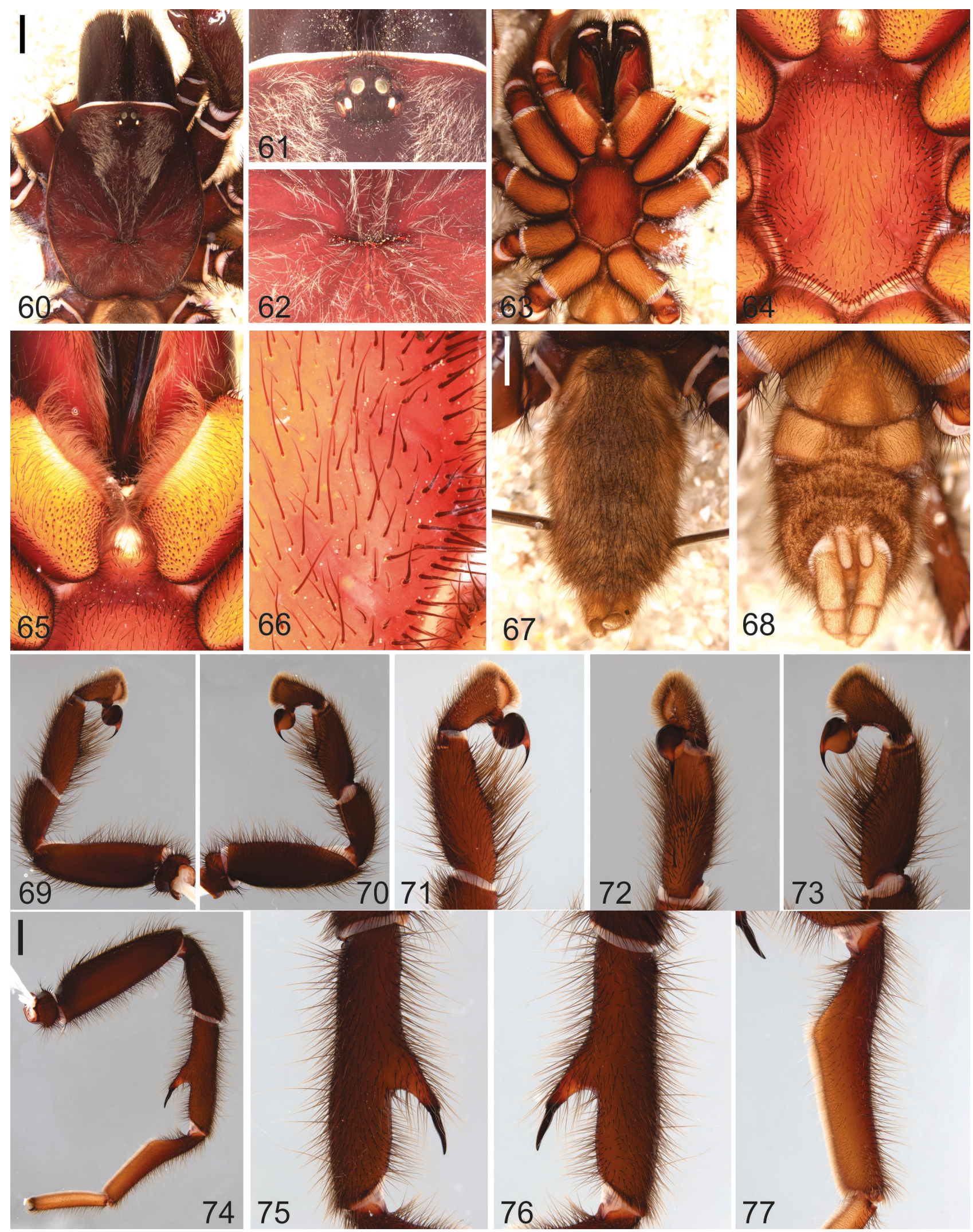

FIGURES 60-77 Aname mccleeryorum sp. nov., holotype male (WAM T53979): 60) cephalothorax, dorsal view; 61) ocular region; 62) fovea; 63) cephalothorax, ventral view; 64) sternum, ventral view; 65) maxillae and labium, ventral view; 66) left sigilla, ventral view; 67) abdomen, dorsal view; 68) abdomen, ventral view; 69) left pedipalp, prolateral view; 70) left pedipalp, retrolateral view; 71) left pedipalp, tibia and tarsus, prolateral view; 72) left pedipalp, tibia and tarsus, ventral view; 73) left pedipalp, tibia and tarsus, retrolateral view; 74) left leg I, prolateral view; 75) left leg I, tibia I, retrolateral view; 76) left leg I, tibia I, prolateral view; 77) left leg I, metatarsus I, prolateral view. Scale lines $=2 \mathrm{~mm}$. 


\section{Female: based on paratype (WAM T142298)}

Colour (in alcohol): Carapace pale brown, with darker V-shaped marking delineating cephalic region; legs brown, some segments with longitudinal pale stripes, tarsi paler; chelicerae deep red-brown; abdomen dorsally base colour grey, with darker grey antero-dorsal patch and several posterior chevrons, and ventrally pale yellow-brown.

Cephalothorax: Carapace (Figure 78) $1.22 \times$ longer than broad; with sparse fine setae, silver hairs sparsely present, with brown bristles dorsally. Clypeal edge protruding medially. Fovea slightly procurved (Figure 80 ). Eyes on distinct mound (Figure 79); from above, anterior eye row straight, posterior eye row slightly recurved; AME about same size as ALE; ALE and AME the largest; PME smallest; eye group length 0.8 , width 1.4. Chelicerae with short black setae, sparsely distributed, 1 well-defined prolateral strip of dense, long, and brown or black setae; rastellum absent; promargin of tooth row with 9 teeth, retromargin with 7 teeth. Labium fused to sternum (Figure 83); without cuspules. Maxillae (Figure 83) with c. 155 cuspules; located on basal third. Sternum (Figure 82): oval, posteriorly pointed; $1.19 \times$ longer than broad; bristles over entire surface; with 3 pairs of sigilla (Figure 84), each pair increasing in size from anterior to posterior; posterior pair elongate and slightly curved; anterior and median pairs located near edge of sternum.
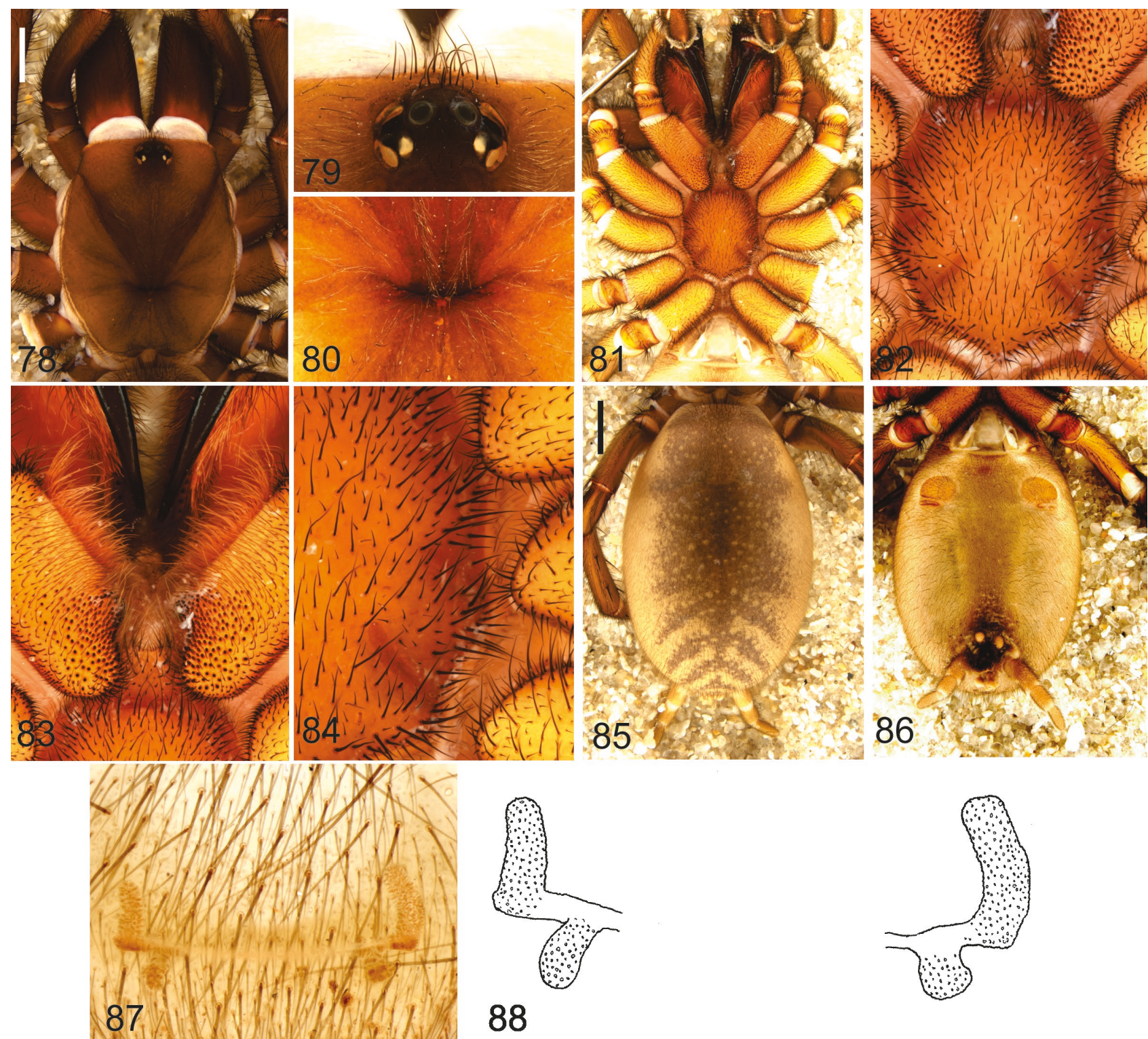

88 79) ocular region; 80) fovea; 81) cephalothorax, ventral view; 82) sternum, ventral view; 83) maxillae and labium, ventral view; 84) left sigilla, ventral view; 85) abdomen, dorsal view; 86) abdomen, ventral view; 87) spermathecae, dorsal view; 88) spermathecae, dorsal view, line drawing. Scale lines $=2 \mathrm{~mm}$. 

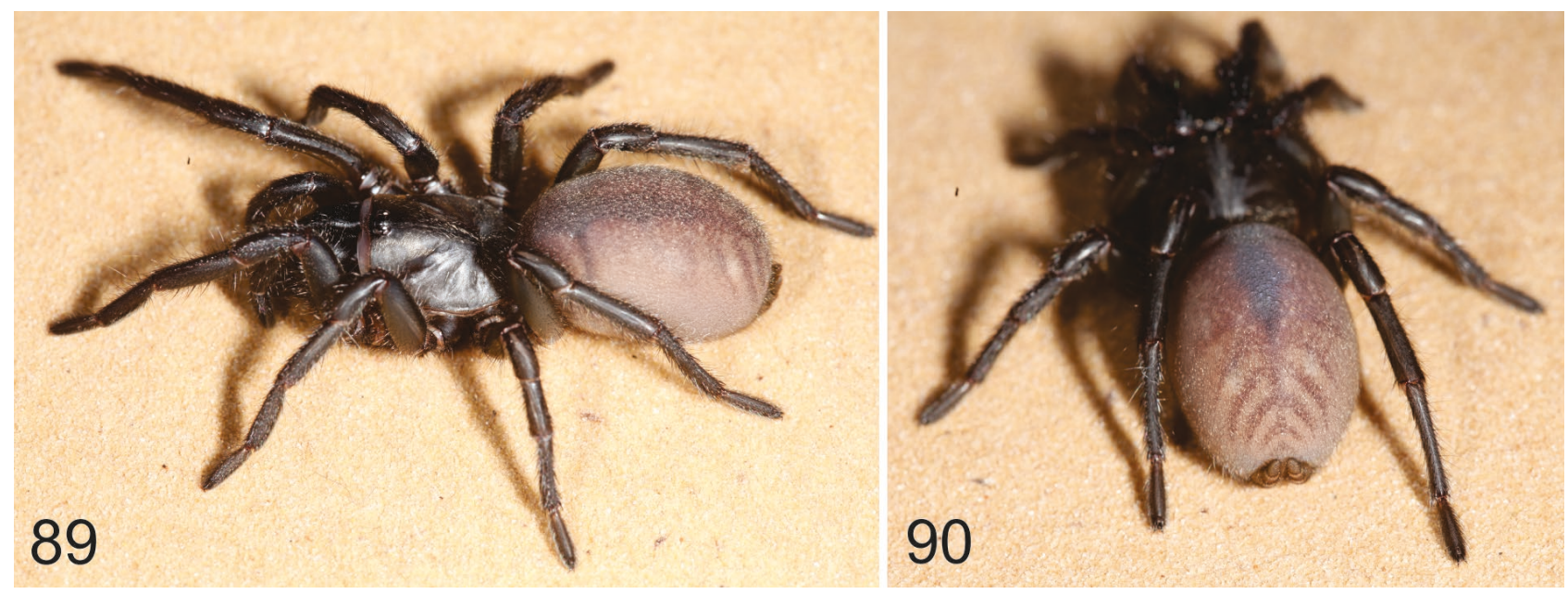

FIGURES 89-90 Aname mccleeryorum sp. nov., paratype juvenile (WAMT142296): 89) lateral view; 90) posterior view.

\section{Pedipalp: Tarsus with thick scopula.}

Legs: Coxal cuspules absent (Figure 81). Scopula present on all tarsi, present on metatarsi I and II, present on distal half of metatarsi III and IV. Trichobothria: tibia with numerous trichobothria in 2 rows, metatarsi with several trichobothria, tarsi with numerous trichobothria. Claws with 2 rows of teeth; claw tufts absent. Measurements: Leg I: femur 6.1. Leg II: femur 5.5. Leg III: femur 5.1. Leg IV: femur 6.1.

Abdomen (Figures 85, 86): $1.5 \times$ longer than broad, sparsely setose. Spinnerets: 2 pairs of spinnerets; PMS unsegmented and separated by about diameter of spinneret; PLS 3-segmented, apical segment elongate, digitiform.

Genitalia (Figures 87, 88): Spermathecal lobes short, gently curved.

Dimensions ( $\mathrm{mm}$ ): Total body length 28.5; carapace length 8.4 , width 6.9 ; sternum length 4.3 , width 3.6 ; abdomen length 10.9, width 7.3.

Variation: $\mathrm{N}=3$; carapace length $10.2-12.2$, width 8.2-8.7; femur I length 6.4-8.1; femur IV length 7.3-7.9.

\section{DISTRIBUTION}

Aname mccleeryorum has been found throughout the Geraldton Sandplains IBRA bioregion of Western Australia, from Oakajee and Chapman Valley south to Lesueur National Park (Figure 151).

\section{REMARKS}

The male holotype of $A$. mccleeryorum was matched to some of the adult females using sequence data (Figure 1). The two males were collected in autumn (April and May).

This species was formerly known by the WAM identification code Aname 'MYG632'.

\section{SEQUENCE DATA}

Within-species genetic divergence for A. mcleeryorum was $2.7 \%$ at $C O I$, suggesting some population genetic structure across its range. It is closely related to $A$. exulans $(7.5 \%)$, which is found on the neighbouring offshore Houtman Abrolhos islands (Figure 151).

\section{ETYMOLOGY}

This species is named for the McCleery family, in recognition of their generous support for the Foundation of the Western Australian Museum.

\section{Aname phillipae Harvey and Huey, sp. nov.}

Figures 91-119

urn:Isid:zoobank.org:act:37FB4C77-4E16-4F80-A652BD4B476E2FF8

\section{MATERIAL EXAMINED}

\section{Holotype}

Australia: Western Australia: Ô, Deception Hill, $111.15 \mathrm{~km}$ NNW. of Koolyanobbing, 2951'56"S, $119^{\circ} 16^{\prime} 37^{\prime \prime E}, 7$ December 2010, dry pitfall trap, R. Teale, Z. Hamilton, V. Cartledge (WAM T110142 ${ }^{\mathrm{DNA}}$ ).

\section{Paratypes}

Australia: Western Australia: 1 त, Deception Hill, $93.10 \mathrm{~km}$ NNW. of Koolyanobbing, 3002'06"S, $119^{\circ} 16^{\prime} 28^{\prime \prime E}, 7$ December 2010, dry pitfall trap, R. Teale, Z. Hamilton, V. Cartledge (WAM T109203 $\left.{ }^{\mathrm{DNA}}\right) ; 1$ ô, Windarling Mine Lease (Portmans), c. 27 $\mathrm{km} \mathrm{N}$. of Mt Jackson, 3000'36.3"S, $119^{\circ} 16^{\prime} 27.0^{\prime \prime E}, 30$ November 2006, dry pitfall trap, open mulga woodland, B.M. Metcalf (WAM T132579); 1 \%, S. of Kambalda, 31 $34^{\prime} 03^{\prime \prime S}, 121^{\circ} 44^{\prime} 42^{\prime \prime E}$, April 2006, S. Thompson (WAM T95772 ${ }^{\mathrm{DNA}}$ ). 

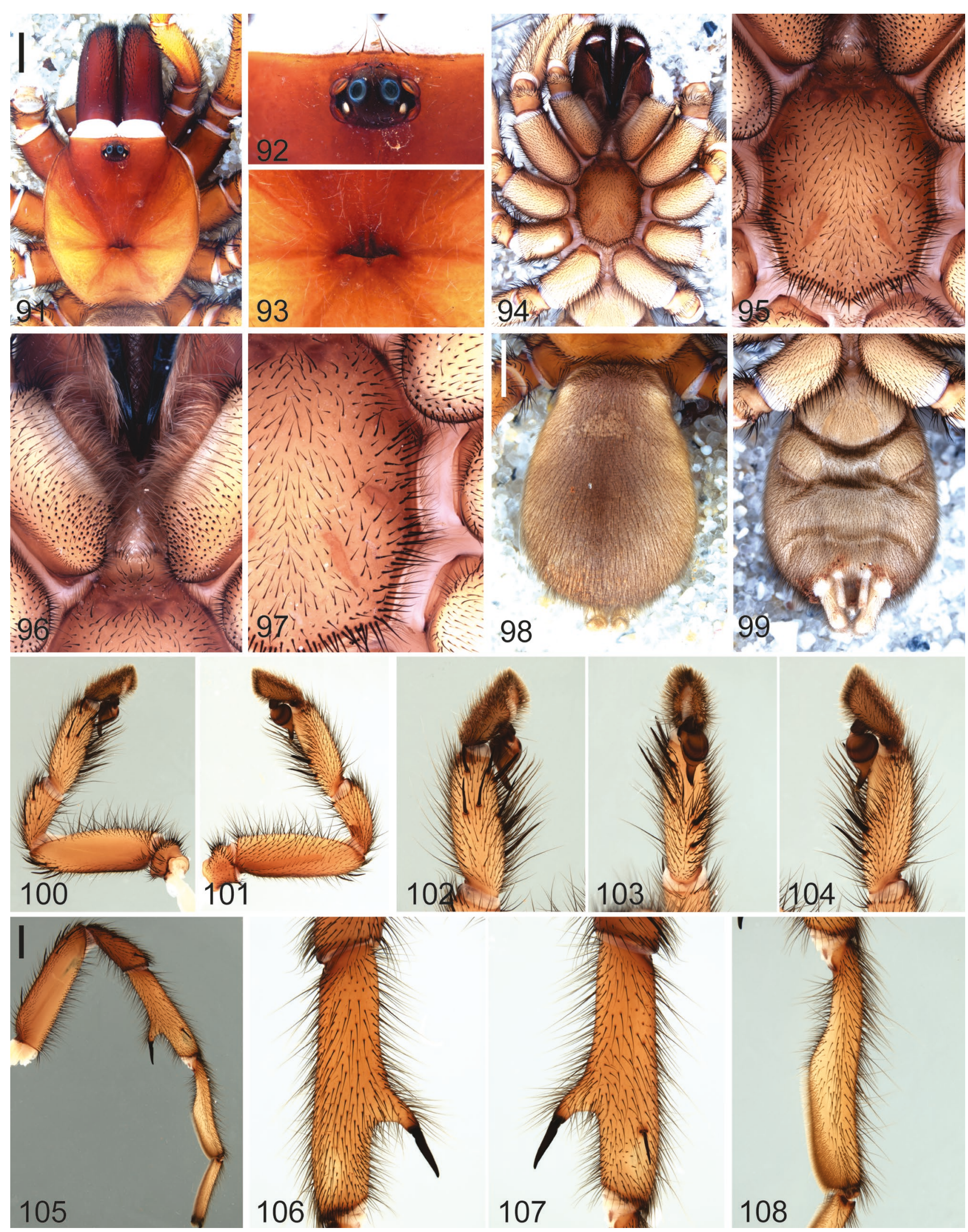

FIGURES 91-108

Aname phillipae sp. nov., holotype male (WAM T110142): 91) cephalothorax, dorsal view; 92) ocular region; 93) fovea; 94) cephalothorax, ventral view; 95) sternum, ventral view; 96) maxillae and labium, ventral view; 97) left sigilla, ventral view; 98) abdomen, dorsal view; 99) abdomen, ventral view; 100) left pedipalp, prolateral view; 101) left pedipalp, retrolateral view; 102) left pedipalp, tibia and tarsus, prolateral view; 103) left pedipalp, tibia and tarsus, ventral view; 104) left pedipalp, tibia and tarsus, retrolateral view; 105) left leg I, prolateral view; 106) left leg I, tibia I, retrolateral view; 107) left leg I, tibia I, prolateral view; 108) left leg I, metatarsus I, prolateral view. Scale lines $=2 \mathrm{~mm}$. 

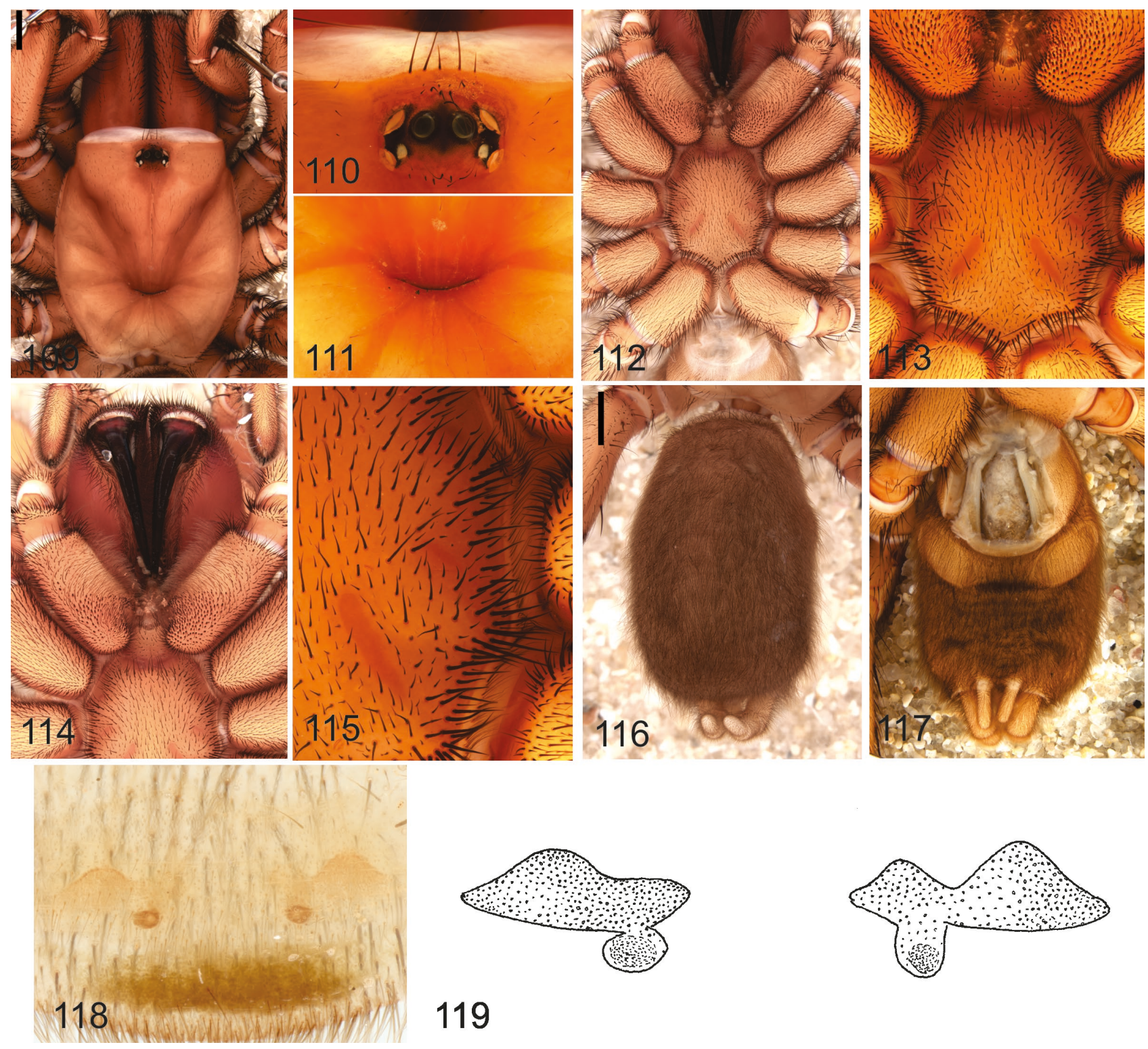

119

FIGURES 109-119 Aname phillipae sp. nov., paratype female (WAM T95772): 109) cephalothorax, dorsal view; 110) ocular region; 111) fovea; 112) cephalothorax, ventral view; 113) sternum, ventral view; 114) maxillae and labium, ventral view; 115) left sigilla, ventral view; 116) abdomen, dorsal view; 117) abdomen, ventral view; 118) spermathecae, dorsal view; 119) spermathecae, dorsal view, line drawing. Scale lines $=2 \mathrm{~mm}$.

\section{Other material}

Australia: Western Australia: 1 đै, Bungalbin Hill, $48.2 \mathrm{~km}$ NNE. of Koolyanobbing, $30^{\circ} 17^{\prime} 38.34 " \mathrm{~S}$, $119^{\circ} 25^{\prime} 30.84 " \mathrm{E}, 12-25$ December 2012, S. White (WAM T127943); 7 §, Lord Nelson [mine], 10.3 $\mathrm{km}$ SSW. of Black Hill, site LN03, 28 $09^{\prime} 36^{\prime \prime S}$, $119^{\circ} 30^{\prime} 36 " \mathrm{E}, 25$ October 2004, dry pitfall trap, M. Craig (WAM T64911-64916 ${ }^{\mathrm{DNA}}$, T72397); 1 กै, Lorna

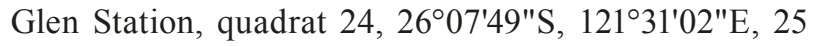
November-1 December 2004, dry pitfall, M.A. Cowan et al. (WAM T66411); 1 ${ }^{\Uparrow}$, Mt Forrest, c. $27 \mathrm{~km} \mathrm{SE}$. of Bulga Downs Homestead, 2841'46"S, 11956'35"E, 12 December 2012, dry pitfall trap, open mulga woodland over open shrubland on plain, G.P. Harewood, G. Murray (WAM T128129); 1 ô, Mt Ida, $80 \mathrm{~km} \mathrm{NW}$. of
Menzies, 29²1'01"S, $120^{\circ} 25^{\prime} 18^{\prime \prime E}, 26$ October 2011, pitfall trap, Eucalyptus woodland, V. Saffer (WAM T121519 $\left.{ }^{\mathrm{DNA}}\right)$.

\section{DIAGNOSIS}

Aname phillipae most closely resembles $A$. whitei, $A$. lillianae and A. simoneae, as adults of all three species are large and rather pale, with extremely narrow third sigilla (Figures 97, 115). Males are most similar to $A$. white $i$ and A. simoneae as the embolus is thickened and flattened (Figure 102-104) but A. phillipae differs from all these species by the embolic tip being noticeably hooked (Figure 103). The female spermathecae, which consist of a low, rounded basal section with a medial anteriorly directed spermatheca with a bulbous distal 
end (Figures 118, 119), cannot be distinguished from those of $A$. whitei and $A$. simoneae, but differ from those of $A$. lillianae which consist of two pairs of long spermathecae of which the median pair are slightly coiled (Figure 59).

\section{DESCRIPTION}

\section{Male: based on holotype (WAM T110142)}

Colour (in alcohol): Carapace cephalic region deep red-brown, thoracic region yellow-brown; leg I red-brown, legs II to IV uniformly yellow-brown; chelicerae uniformly dark red-brown; abdomen greybrown.

Cephalothorax: Carapace (Figure 91) $1.11 \times$ longer than broad; with sparse fine setae, silver hairs present, with brown bristles dorsally. Clypeal edge straight. Fovea slightly procurved (Figure 93). Eyes (Figure 92) on distinct mound; from above, anterior eye row straight, posterior eye row slightly recurved; AME about same size as ALE; ALE and AME the largest; PME smallest; eye group length 0.82 , width 1.01 . Chelicerae with broad dorsal strip of black setae, and 2 thinner lateral strips of smaller black setae; rastellum absent; promargin of tooth row with 10 teeth, retromargin with 4 teeth. Labium fused to sternum (Figure 96); without cuspules. Maxillae (Figure 96) with 112 cuspules; located on basal half. Sternum (Figure 95): oval, posteriorly pointed; $1.18 \times$ longer than broad; bristles over entire surface. With 3 pairs of very faint sigilla (Figure 97); each pair increasing in size from anterior to posterior; posterior pair elongate and slightly curved.

Pedipalp (Figures 100-104): Tibia cylindrical, narrow; asetose depression present, about the length of embolus; PDL/PTL 0.49. Tarsus short, broadest distally; densely setose; bulb ovoid; embolus shorter than bulb, flattened, terminating in constricted and slightly hooked tip.

Legs: Coxa I with 2-3 cuspules near medial edge of coxa I (Figures 94, 95). Tibia I with large megaspur (Figures 105-107); TIL/TID 4.11; TIS/TIL 0.62; TISH/TID 0.71; metatarsus incrassate (Figure 108); MIL/MID 5.04; MIPEL/MIL 0.52. Scopula present on tarsi and metatarsi of all legs. Trichobothria: tibia with numerous trichobothria in 2 rows, metatarsi with several trichobothria, tarsi with numerous trichobothria. Claws with 2 rows of teeth; claw tufts absent. Measurements: Leg I: femur 8.5, tibia 8.4, metatarsus 6.4. Leg II: femur 7.9. Leg III: femur 6.7. Leg IV: femur 8.5.

Abdomen (Figures 98, 99): $1.4 \times$ longer than broad, densely pilose. Spinnerets: 2 pairs of spinnerets; PMS unsegmented and separated by about diameter of spinneret; PLS 3-segmented, apical segment elongate, digitiform.

Dimensions (mm): Total body length 18.4; carapace length 8.8 , width 7.9 ; sternum length 4.5 , width 3.8 ; abdomen length 9.2, width 6.4 .
Variation: $\mathrm{N}=10$; carapace length 8.2-9.4; width 7.58.2; femur I length 7.3-8.7; metatarsus I length 5.7-6.7; femur IV length 8.2-9.6.

\section{Female: based on paratype (WAM T95772)}

Colour (in alcohol): Carapace anterior brown-yellow fading to yellow-brown posteriorly; legs uniformly redbrown; chelicerae yellow-brown; abdomen grey-brown.

Cephalothorax: Carapace (Figure 109) $1.19 \times$ longer than broad; with sparse fine setae, silver hairs absent, with brown bristles dorsally. Clypeal edge protruding medially. Fovea slightly procurved (Figure 111). Eyes on distinct mound (Figure 110); from above, anterior eye row slightly procurved, posterior eye row slightly recurved; AME larger than ALE; ALE largest; PME smallest; eye group length 0.96 , width 1.88 . Chelicerae with short black setae, sparsely distributed, with 1 well-defined prolateral strip dense, long, and brown or black setae; rastellum absent; promargin of tooth row with 10 teeth, retromargin with 4 teeth. Labium fused to sternum (Figure 114); with 1 cuspule. With c. 210 cuspules; located in basal half. Sternum (Figure 113): oval, posteriorly pointed; $1.14 \times$ longer than broad; bristles over entire surface; with 3 pairs of sigilla (Figure 115), each pair increasing in size from anterior to posterior; anterior pair located near edge of sternum; posterior pair elliptical.

Pedipalp: Tarsus with thick scopula.

Legs: Coxal cuspules absent (Figure 112). Scopula present on all tarsi, present on metatarsi I and II, present on distal half of metatarsi III and IV. Trichobothria: tibia with numerous trichobothria in 2 rows, metatarsi with several trichobothria, tarsi with numerous trichobothria. Claws with 2 rows of teeth; claw tufts absent. Measurements: Leg I: femur 9.2. Leg II: femur 8.2. Leg III: femur 7.3. Leg IV: femur 9.4.

Abdomen (Figures 116, 117): $1.4 \times$ longer than broad, densely pilose. Spinnerets: 2 pairs of spinnerets; PMS unsegmented and separated by about diameter of spinneret; PLS 3-segmented, apical segment elongate, digitiform.

Genitalia (Figures 118, 119): Low, rounded basal section with medial anteriorly directed spermatheca, with bulbous distal end.

Dimensions ( $\mathrm{mm}$ ): Total body length 25; carapace length 11.6, width 9.8; sternum length 5.8, width 5.1; abdomen length 10.9, width 7.7 .

\section{DISTRIBUTION}

Aname phillipae has been found in the Gascoyne, Murchison and Coolgardie IBRA bioregions of Western Australia (Figure 151).

\section{REMARKS}

The female was matched with the males using sequence data (Figure 1). Males have been collected in pitfall traps during the spring and summer months of October to December. 
This species was formerly known by the WAM identification code Aname 'MYG604'.

\section{SEOUENCE DATA}

Despite showing significant genetic structure in the concatenated phylogeny (Figure 1), only one specimen was successfully sequenced at COI. This genetic structure was primarily based on structure in $16 \mathrm{~S}$ (data not shown). Aname phillipae is closely related to A. simoneae and $A$. whitei, to which it is very similar morphologically.

\section{ETYMOLOGY}

This species is named for Phillipa Huey, daughter of Joel A. Huey.

\section{Aname simoneae Harvey and Huey, sp. nov.}

Figures 120-150

\section{urn:Isid:zoobank.org:act:C2D21926-A117-468F-A25A- 6EC0E01CED4E}

Aname MY2121: Hedin and Bond 2006: figs 4, 5; Bond et al. 2012: figs 1, 2; Wheeler et al. 2017: fig. 2; Opatova et al. 2020: fig. 3 (which states 'MY2131').

\section{MATERIAL EXAMINED}

\section{Holotype}

Australia: Western Australia: $\hat{0}, 21 \mathrm{~km}$ S. of Laverton, 2847'34"S, 122²5'53"E, 8 January 2011, pit trap, S.A. Thompson (WAM T110261 ${ }^{\mathrm{DNA}}$ ).

\section{Paratypes}

Australia: Western Australia: 1 ô, Lake Way, 15 $\mathrm{km}$ SSE. of Wiluna, 26 50'33"S, 120²1'47"E, 10 March 2010, P. Bolton (WAM T101218); 1 ㅇ, same data except 24 October 2007 (WAM T104712); 1 9, c. $41.5 \mathrm{~km} \mathrm{SSE}$. of Menzies, 3004'21.91"S, 12110'35.75"E, 4 May 2018, dug from burrow, E.S. Volschenk (WAM T149148 ${ }^{\text {DNA }}$ ).

\section{Other material}

Australia: Western Australia: 2 ô, Black Swan Nickel Mine, $50 \mathrm{~km} \mathrm{NE}$. of Kalgoorlie, 30²3'54"S, 12140'53"E, 12 December 2003-5 January 2004, pitfall trap, P.R. Langlands (WAM T56915); 1 ô, Bulong, $30^{\circ} 45^{\prime} \mathrm{S}, 121^{\circ} 48^{\prime} \mathrm{E}, 1$ December 1932, F. Jones (WAM T2500, formerly 32/2686); 2 ơ, Goldminer Caravan Park, Kalgoorlie, 3044'S, $121^{\circ} 28^{\prime}$ E, 20 January 1993, G. Thompson (WAM T27289-27290, formerly 93/605606); 1 Oे, Mt Vetters Station, Black Swan Nickel Mine, $50 \mathrm{~km} \mathrm{NE}$. of Kalgoorlie, 30²3'56"S, 121 ${ }^{\circ} 41^{\prime} 06^{\prime \prime E}$, 12 December 2003, 5 January 2004, pitfall trap, P.R. Langlands (WAM T56960); 3 ô, Ora Banda, 30²3'S, $121^{\circ} 04^{\prime} \mathrm{E}$, January 2006, S. Thompson (WAM T95768); 1 o, 7-8 km WNW. of Point Salvation, red sands site, $28^{\circ} 12^{\prime} \mathrm{S}, 123^{\circ} 36^{\prime} \mathrm{E}, 27$ December 1995, pitfall trap, E.R.
Pianka (WAM T44223); 1 juvenile, Wanjarri, $53.3 \mathrm{~km}$ S. of Lake Way homestead, site YAK07B, 27²4'24"S, $120^{\circ} 36^{\prime} 42^{\prime \prime E}$, dug from burrow, 4 December 2005, R. Teale (WAM T76834 ${ }^{\mathrm{DNA}}$ ).

\section{DIAGNOSIS}

Aname simoneae most closely resembles $A$. whitei, A. lillianae and $A$. phillipae as adults of all three species are large and rather pale, with extremely narrow third sigilla (Figures 97, 115). Males are most similar to $A$. whitei and $A$. phillipae as the embolus is thickened and flattened (Figures 131-133) but differ from A. phillipae by the lack of distinct terminal hook and from $A$. white by the shape of the embolus which is more evenly tapered. The embolus of $A$. lillianae is slender and tapering. The female spermathecae, which consist of a low, rounded basal section with a medial anteriorly directed spermatheca with a bulbous distal end (Figures 147, 148), cannot be distinguished from those of $A$. whitei and $A$. phillipae, but differ from those of $A$. lillianae which consist of two pairs of long spermathecae of which the median pair are slightly coiled (Figure 59).

\section{DESCRIPTION}

\section{Male: based on holotype (WAM T110261)}

Colour (in alcohol): Carapace anterior light orangebrown fading posteriorly to pale yellow; leg I red-brown, legs II to IV uniformly yellow-brown; chelicerae burnt orange; abdomen dorsally pale creamy-yellow, and ventrally pale creamy-yellow.

Cephalothorax: Carapace (Figure 120) $1.22 \times$ longer than broad; with sparse short setae, silver hairs absent; without dorsal bristles. Clypeal edge straight. Fovea slightly procurved (Figure 122). Eyes on distinct mound (Figure 121); from above, anterior eye row procurved, posterior eye row nearly straight; AME larger than ALE; ALE largest; PME smallest; eye group length 0.96, width 1.58 . Chelicerae with short black setae, sparsely distributed; with 1 well-defined prolateral strip of dense, long, and brown or black setae; rastellum absent; promargin of tooth row with 10 teeth, retromargin with 4 or 5 teeth. Labium fused to sternum (Figure 125); without cuspules. Maxillae (Figure 125) with c. 134 cuspules; located on basal half. Sternum (Figure 124): oval, posteriorly pointed; $1.18 \times$ longer than broad; bristles over entire surface; with 3 pairs of sigilla (Figure 126), each pair increasing in size from anterior to posterior; anterior pair located near edge of sternum; posterior pair elliptical.

Pedipalp (Figures 129-133): Tibia cylindrical, narrow; asetose depression present, about the length of embolus; PDL/PTL 0.39; densely setose; bulb ovoid; embolus shorter than bulb, flattened, terminating in constricted tip.

Legs: Coxal cuspules absent (Figure 123). Tibia I with large megaspur (Figures 134-136); TIL/TID 4.58; TIS/ TIL 0.61; TISH/TID 1.08; metatarsus slightly incrassate (Figure 137); MIL/MID 5.24; MIPEL/MIL 0.48. 

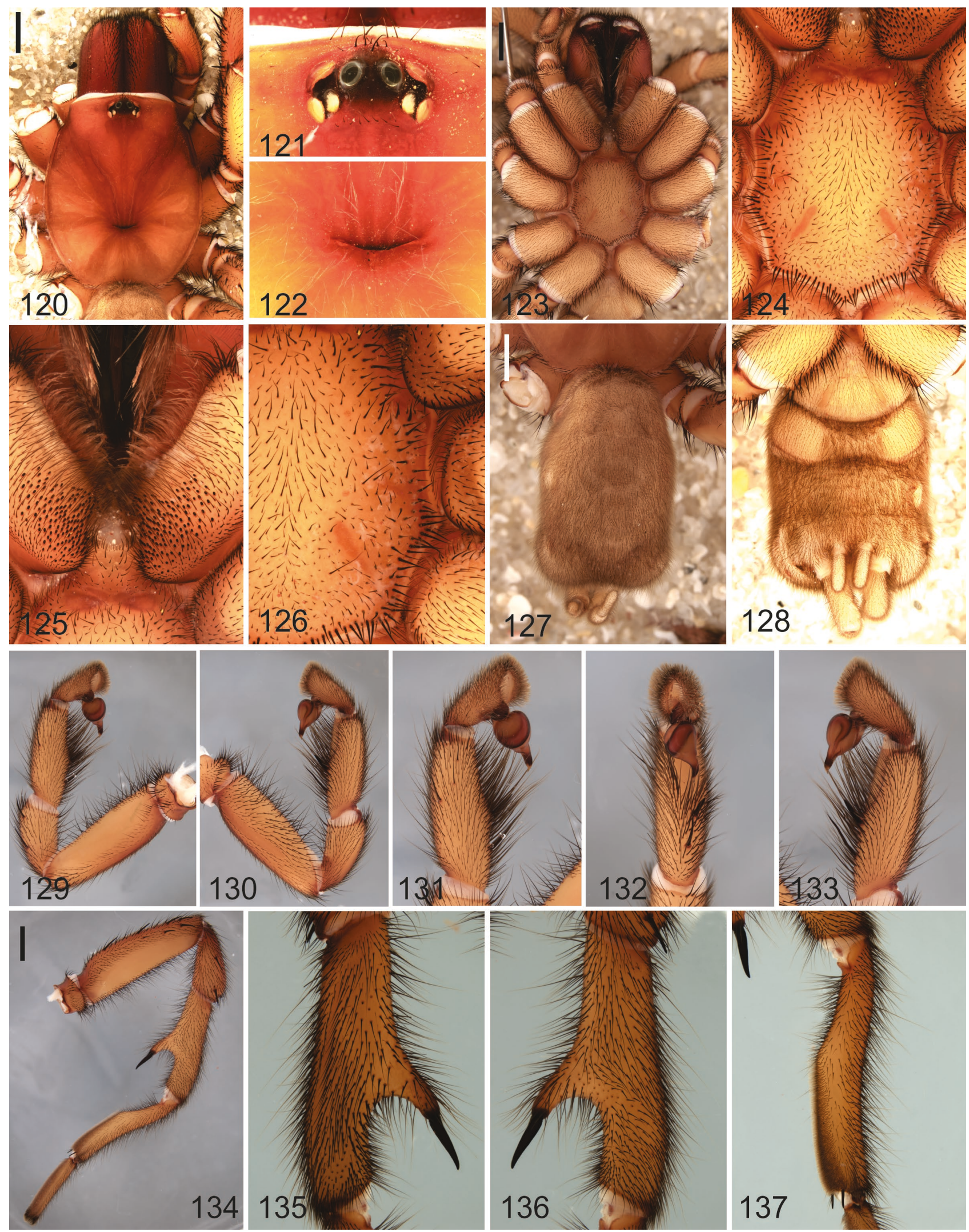

FIGURES 120-137 Aname simoneae sp. nov., holotype male (WAMT110261): 120) cephalothorax, dorsal view; 121) ocular region; 122) fovea; 123) cephalothorax, ventral view; 124) sternum, ventral view; 125) maxillae and labium, ventral view; 126) left sigilla, ventral view; 127) abdomen, dorsal view; 128) abdomen, ventral view; 129) left pedipalp, prolateral view; 130) left pedipalp, retrolateral view; 131) left pedipalp, tibia and tarsus, prolateral view; 132) left pedipalp, tibia and tarsus, ventral view; 133) left pedipalp, tibia and tarsus, retrolateral view; 134) left leg I, prolateral view; 135) left leg I, tibia I, retrolateral view; 136) left leg I, tibia I, prolateral view; 137) left leg I, metatarsus I, prolateral view. Scale lines $=2 \mathrm{~mm}$. 

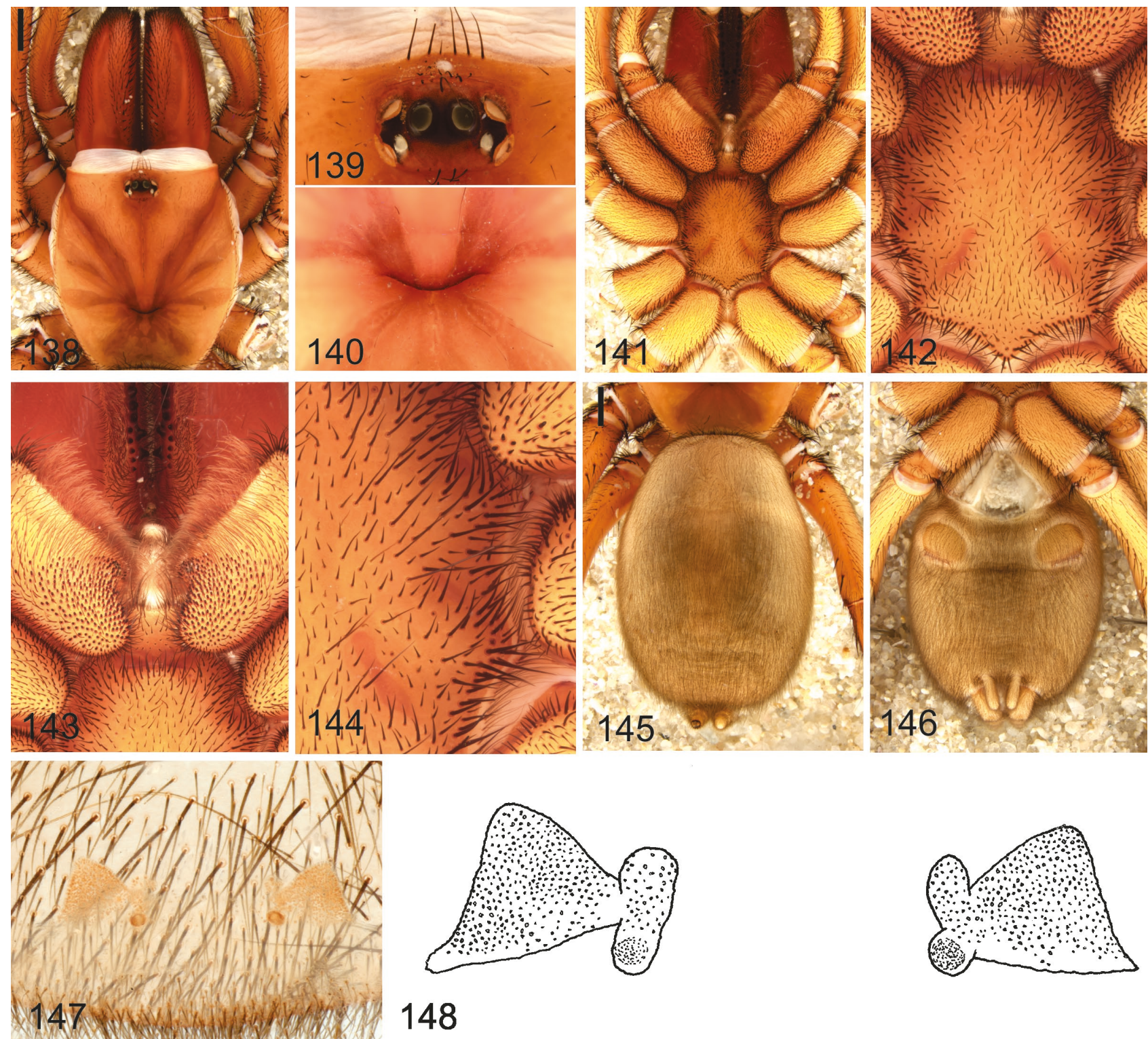

148

FIGURES 138-148 Aname simoneae sp. nov., paratype female (WAMT149148): 138) cephalothorax, dorsal view; 139) ocular region; 140) fovea; 141) cephalothorax, ventral view; 142) sternum, ventral view; 143) maxillae and labium, ventral view; 144) left sigilla, ventral view; 145) abdomen, dorsal view; 146) abdomen, ventral view; 147) spermathecae, dorsal view; 148) spermathecae, dorsal view, line drawing. Scale lines $=2 \mathrm{~mm}$.

Scopula present on all tarsi, and metatarsi I and II. Trichobothria: tibia with numerous trichobothria in 2 rows, metatarsi with several trichobothria, tarsi with numerous trichobothria. Claws with 2 rows of teeth; claw tufts absent. Measurements: Leg I: femur 8.1, tibia 8.5, metatarsus 7.2. Leg II: femur 7.8. Leg III: femur 7.0. Leg IV: femur 7.7.

Abdomen (Figures 127, 128): $1.6 \times$ longer than broad, densely pilose. Spinnerets: 2 pairs of spinnerets; PMS unsegmented and separated by about diameter of spinneret; PLS 3-segmented, apical segment elongate, digitiform.

Dimensions ( $\mathrm{mm}$ ): Total body length 24.0; carapace length 9.8 , width 8.0 ; sternum length 4.8 , width 4.1 ; abdomen length 9.4 , width 5.8 .
Variation: $\mathrm{N}=10$; carapace length 9.3-13.3; width 8.1-10.1; femur I length 8.4-9.7; metatarsus I length 7.1-7.7; femur IV length 9.1-10.2.

\section{Female: based on paratype (WAM T149148)}

Colour (in alcohol): Carapace dark yellow-brown with red-brown radial markings; legs uniformly red-brown; chelicerae uniformly dark red-brown; abdomen greybrown.

Cephalothorax: Carapace (Figure 138) $1.04 \times$ longer than broad; with sparse fine setae, silver hairs absent, with brown bristles dorsally. Clypeal edge protruding medially. Fovea slightly procurved (Figure 140). Eyes on distinct mound (Figure 139); from above, anterior eye row slightly procurved, posterior eye row slightly 

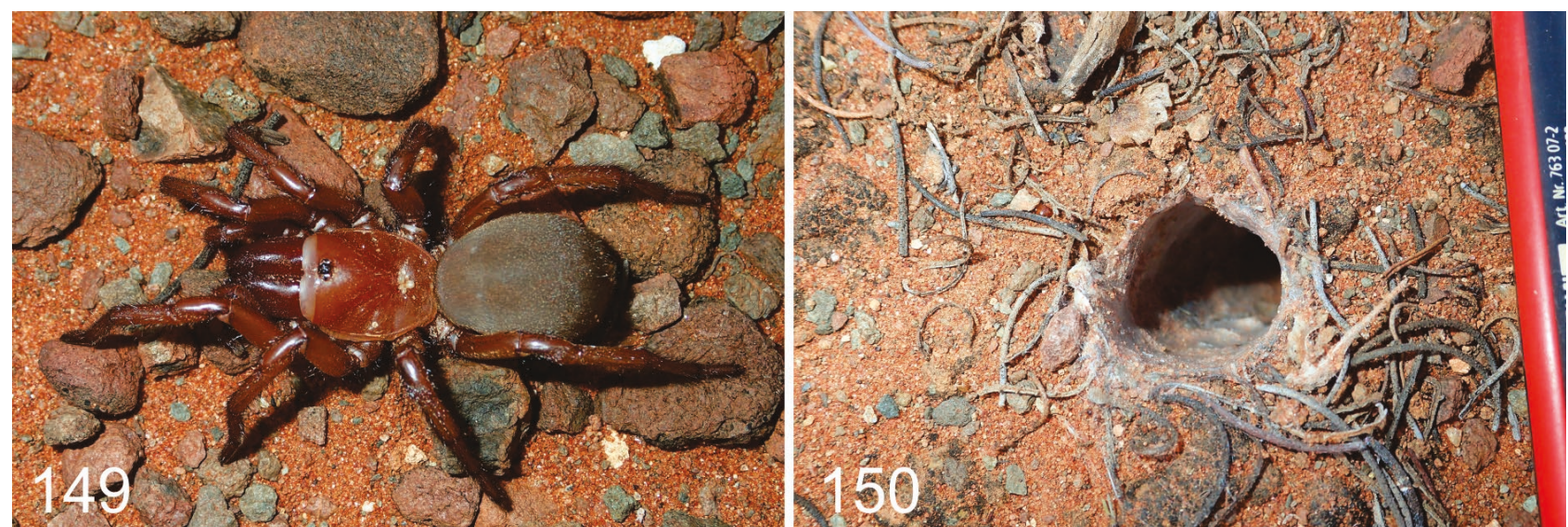

FIGURES 149-150 Aname simoneae sp. nov., paratype female (WAMT149148): 149, dorsal view; 150, burrow entrance. (Image courtesy Erich Volschenk.)

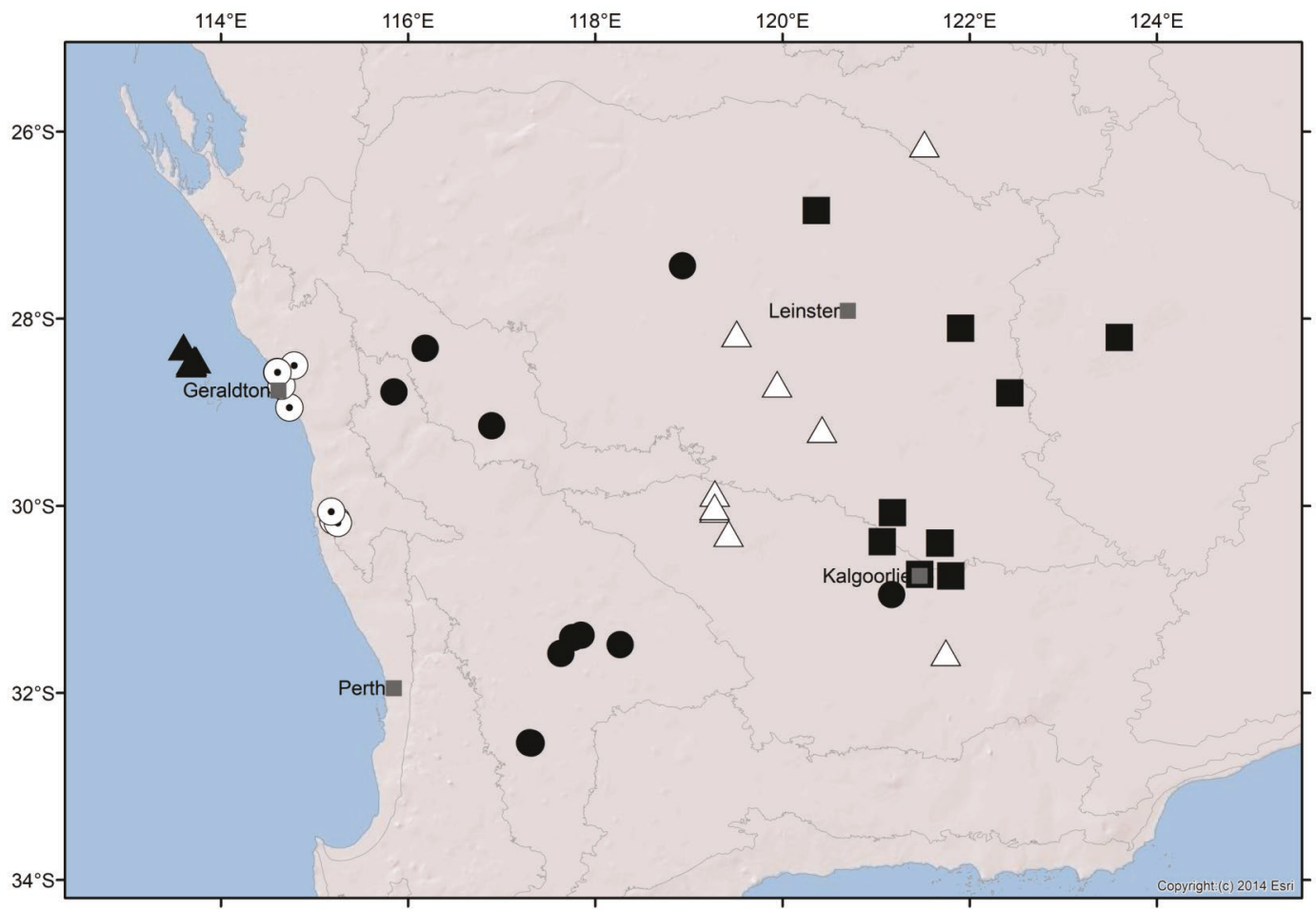

FIGURE $151 \quad$ Known distributions of the Aname species treated in this paper, superimposed over IBRA bioregions: Aname exulans sp. nov. (solid triangle); A. lillianae sp. nov. (solid circle); A. mccleeryorum sp. nov. (open circle); A. phillipae sp. nov. (open triangle); A. simoneae sp. nov. (solid square).

recurved; AME about same size as ALE; ALE and AME the largest; PME smallest; eye group length 1.0, width 1.8. Chelicerae with broad dorsal strip of black setae, and two thinner lateral strips of smaller black setae; rastellum absent; promargin of tooth row with 11 teeth, retromargin with 5 teeth. Labium fused to sternum (Figure 143); without cuspules. Maxilla (Figure 143) with c. 215 cuspules; located on basal half. Sternum (Figure 142): oval, posteriorly pointed; $1.2 \times$ longer than broad; bristles over entire surface; with 3 pairs of sigilla (Figure 144), each pair increasing in size from anterior to posterior; anterior pair located near edge of sternum; posterior pair elongate.

Pedipalp: Tarsus with thick scopula.

Legs: Coxal cuspules absent (Figure 141). Scopula present on all tarsi, present on metatarsi I and II. Trichobothria: tibia with numerous trichobothria in 2 rows, metatarsi with several trichobothria, tarsi with numerous trichobothria. Claws with 2 rows of teeth; claw tufts absent. Measurements: Leg I: femur 8.9. Leg II: femur 8.1. Leg III: femur 7.2. Leg IV: femur 9.3. 

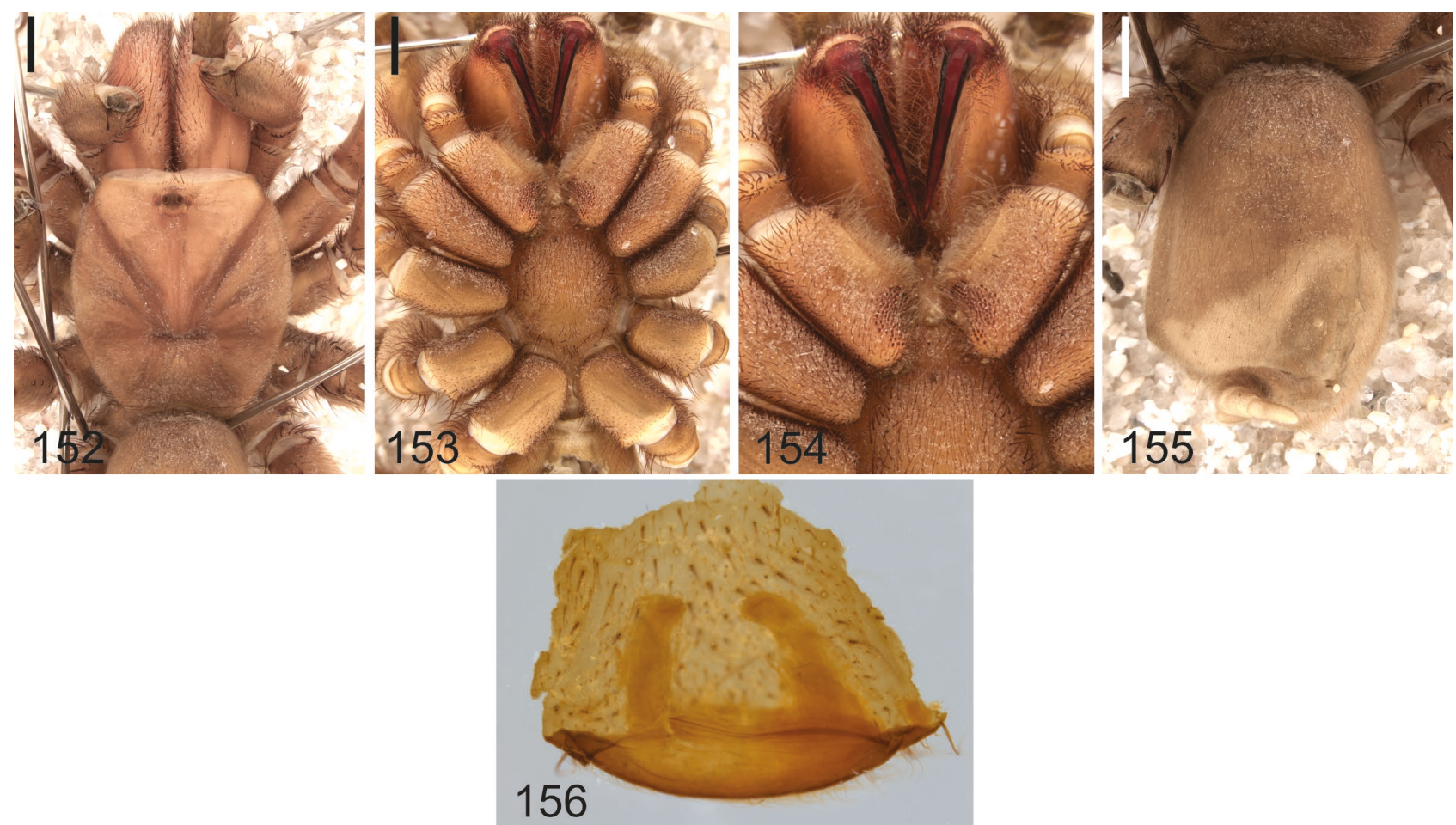

FIGURES 152-156 Proshermacha armigera, holotype female (AM KS8193): 152) cephalothorax, dorsal view; 153) cephalothorax, ventral view; 154) maxillae, labium and sternum, ventral view; 155) abdomen, dorsal view; 156) spermathecae, dorsal view. Scale lines $=2 \mathrm{~mm}$.

Abdomen (Figures 145, 146): $1.5 \times$ longer than broad, densely pilose. Spinnerets: 2 pairs of spinnerets; PMS unsegmented and separated by about diameter of spinneret; PLS 3-segmented, apical segment elongate, digitiform.

Genitalia (Figures 147, 148): Low, rounded basal section with medial anteriorly directed spermatheca, with bulbous distal end.

Dimensions $(\mathrm{mm})$ : Total body length 24.0; carapace length 9.9, width 9.5; sternum length 6.0 , width 5.0; abdomen length 15.5, width 10.7 .

Variation: $\mathrm{N}=1$; carapace length 10.6, width 8.3; femur I length 7.8; femur IV length 8.5.

\section{DISTRIBUTION}

Aname simoneae has been found in the Coolgardie, Great Victoria Desert and Murchison IBRA bioregions of Western Australia (Figure 151).

\section{REMARKS}

The female used for the description was matched with the male holotype using sequence data (Figure 1). The other female was collected from the same locality as a male. Males have been collected in pitfall traps during the summer months of December to March.

Our sequence data matched those of a specimen identified as Aname MY2121 in previous studies examining mygalomorph spider phylogenetics (Bond et al. 2012; Hedin and Bond 2006; Wheeler et al. 2017), and we are confident that this sample represents
A. simoneae. Although the locality was given as ' $\mathrm{N}$ of Leonora S28.10172 E125.90417' by Hedin and Bond (2006), the site is actually located at S28.10172 E121.90417 (M. Hedin, in litt.).

This species was formerly known by the WAM identification code Aname 'MYG523'.

\section{SEQUENCE DATA}

Intraspecific genetic distances are high within $A$. simoneae (8.98\%). Aname simoneae is closely related to $A$. phillipae and $A$. whitei, to which it is very similar morphologically.

\section{ETYMOLOGY}

This species is named for Simone Huey, wife of Joel A. Huey.

\section{Genus Proshermacha Simon, 1908}

Proshermacha Simon, 1908: 363. Type species: Proshermacha subarmata Simon, 1908, by subsequent designation of Rainbow (1911).

\section{REMARKS}

The genus Proshermacha was recently reinstated by Harvey et al. (2018) for a group of species from southern Australia that could be best diagnosed by characters found in the male pedipalp. Although the genus contains eight species, numerous new species have been observed in museum collections (Harvey et al. 2018). 


\section{Proshermacha armigera (Rainbow and Pulleine, 1918) comb. nov.,}

Figures 152-156

urn:Isid:zoobank.org:act:47ECBBF8-E50F-401F-9E49F066921C163E

Aname armigera Rainbow and Pulleine, 1918: 150, plate 23, figs 102, 103.

\section{MATERIAL EXAMINED}

\section{Holotype}

Australia: Western Australia: 9 , Mullewa [as 'Mullawa' (sic)] [2832'S, $\left.115^{\circ} 31^{\prime} \mathrm{E}\right]$, date unknown, F. May (AM KS8193).

\section{DESCRIPTION}

\section{Female: based on holotype (AM KS8193)}

Colour (in alcohol): Carapace uniformly yellowbrown; indeterminate (faded); chelicerae yellow-brown; abdomen dorsally grey-brown, and ventrally pale yellow-brown.

Cephalothorax: Carapace (Figure 152) $1.14 \times$ longer than broad, densely pilose, silver hairs present, with brown bristles dorsally. Clypeal edge protruding medially. Fovea slightly procurved (Figure 154). Eyes on distinct mound (Figure 153); from above, anterior eye row straight, posterior eye row slightly recurved; AME larger than ALE; ALE and AME the largest; PME smallest; eye group length 0.6 , width 1.4. Chelicerae with 2 well-defined rows of short black spines; rastellum absent; promargin of tooth row with 8 teeth, retromargin with 10 teeth. Labium fused to sternum (Figure 154); with 3 cuspules. Maxilla with c. 100 cuspules; located on the proximo-basal edge (Figure 154). Sternum (Figure 153): oval, posteriorly pointed; $1.16 \times$ longer than broad; bristles over entire surface; with 3 pairs of sigilla (Figure 153), each pair increasing in size from anterior to posterior; anterior and median pairs located near edge of sternum.

Pedipalp: Tarsus densely setose.

Legs: Coxal cuspules absent (Figure 153). Trichobothria: tibia with numerous trichobothria in 2 rows, metatarsi with several trichobothria, tarsi with numerous trichobothria. Claws with 2 rows of teeth; claw tufts absent. Measurements: Leg I: femur 8.8. Leg II: femur 6.4. Leg III: femur 4.5. Leg IV: femur 6.9.

Abdomen (Figure 155): $1.4 \times$ longer than broad, densely pilose with bristles. Spinnerets: 2 pairs of spinnerets; PMS unsegmented and separated by about diameter of spinneret; PLS 3-segmented, apical segment elongate, digitiform.

Genitalia (Figure 156): 1 pair of widely spaced, thickened, anteriorly directed spermathecae.

Dimensions $(\mathrm{mm})$ : Total body length 21.1; carapace length 8.3 , width 7.3 ; sternum length 4.3 , width 3.7 ; abdomen length 8.7 , width 6.2 .

\section{DISTRIBUTION}

Proshermacha armigera is known only from the holotype collected from Mullewa in the northern section of the Avon Wheatbelt IBRA region, Western Australia.

\section{REMARKS}

The original description of $A$. armigera was based on a single female collected from Mullewa in the north-western Wheatbelt region of Western Australia, although the locality was incorrectly stated to be 'Mullawa' (Rainbow and Pulleine 1918). The holotype is in fair condition, but many of the legs have become separated from the body.

As stated above, Proshermacha is best diagnosed by a combination of features found in males, including the presence of a large ventral tibial spur on leg I, the lack of a ventral asetose depression on the male pedipalpal tibia, the long embolus, and the lack of thickened setae on the retrolateral face of the male pedipalpal tibia, which renders the placement of the female holotype of $A$. armigera slightly problematic. The maxillary cuspules are restricted to the baso-mesal edge of the maxillae (Figure 154), which excludes it from Aname where the cuspules are spread over the entire basal half of the maxilla (Harvey et al. 2018). The restricted conformation is only known from species of Chenistonia, Proshermacha and Teyl, at least among the Western Australian anamid fauna. The general body plan does not resemble species of Teyl which tend to have gracile legs and rounded abdomens. Species of Chenistonia have only been recorded from mesic regions of southern Western Australia and have never been found in the mid-west region (MSH, JAH, unpublished data). Therefore, we here transfer $A$. armigera to the genus Proshermacha which have similarly shaped spermathecae (Harvey et al. 2018, figure 7G). There are no obvious morphological features that would help to distinguish $P$. armigera from others in the genus, and we have not been able to match the female with males of Proshermacha collected in the general vicinity of the type locality.

\section{SEQUENCE DATA}

Molecular data are not available for this species.

\section{ACKNOWLEDGEMENTS}

We are very grateful to Graham Milledge (Australian Museum, Sydney) for kindly lending the holotype of Aname armigera, and Erich Volschenk for supplying images and sequence data for a female of Aname simoneae. Part of this study was funded by the Gorgon Barrow Island Net Conservation Benefits Fund. The Fund is administered by the Department of Biodiversity, Conservation and Attractions and approved by the Minister for Environment after considering advice from the Gorgon Barrow Island Net Conservation Benefits Advisory Board. We also wish to thank the many collectors who contributed specimens to this study, without whom this study would have been impossible. 
We also thank Michael Rix (Queensland Museum, Brisbane, Australia) and Jeremy Wilson (Museo Argentino de Ciencias Naturales, Buenos Aires, Argentina).

\section{REFERENCES}

Bond, J.E., Hendrixson, B.E., Hamilton, C.A. and Hedin, M. (2012). A reconsideration of the classification of the spider infraorder Mygalomorphae (Arachnida: Araneae) based on three nuclear genes and morphology. PLoS One 7 6: e38753. doi: 10.1371/journal.pone.0038753.

Brown, R.W. (1956). Composition of scientific words. (Smithsonian Institution Press: Washington, D.C.).

Castalanelli, M.A., Framenau, V.W., Huey, J.A., Hillyer, M.J. and Harvey, M.S. (2020). New species of the open-holed trapdoor spider genus Aname (Araneae: Mygalomorphae: Anamidae) from arid Western Australia. Journal of Arachnology 48(2): 169-213. doi: 10.1636/0161-820248.2.169.

Castalanelli, M.A., Teale, R., Rix, M.G., Kennington, J.W. and Harvey, M.S. (2014). Barcoding of mygalomorph spiders (Araneae: Mygalomorphae) in the Pilbara bioregion of Western Australia reveals a highly diverse biota. Invertebrate Systematics 28: 375-385. doi: 10.1071/IS13058.

Castresana, J. (2000). Selection of conserved blocks from multiple alignments for their use in phylogenetic analysis. Molecular Biology and Evolution 17: 540-552. doi: 10.1093/oxfordjournals.molbev.a026334.

Collins, L.B., Zhao, J.-X. and Freeman, H. (2006). A highprecision record of mid-late Holocene sea-level events from emergent coral pavements in the Houtman Abrolhos Islands, southwest Australia. Quaternary International 145146: 78-85. doi: 10.1016/j.quaint.2005.07.006.

Dallwitz, M.J., Paine, T.A. and Zurcher, E.J. (2010). User's guide to the DELTA editor, 11 January 2010. Accessed on 20 October 2014. http://delta-intkey.com/www/delta-ed.htm (CSIRO: Canberra).

Environment Australia (2000). Revision of the Interim Biogeographic Regionalisation for Australia (IBRA) and Development of Version 5.1. (Environment Australia: Canberra).

Harvey, F.S.B., Framenau, V.W., Wojcieszek, J.M., Rix, M.G. and Harvey, M.S. (2012). Molecular and morphological characterisation of new species in the trapdoor spider genus Aname (Araneae: Mygalomorphae: Nemesiidae) from the Pilbara bioregion of Western Australia. Zootaxa 3383: 15-38. doi: 10.11646/zootaxa.3383.1.3.

Harvey, M.S., Hillyer, M.J., Main, B.Y., Moulds, T.A., Raven, R.J., Rix, M.G., Vink, C.J. and Huey, J.A. (2018). Phylogenetic relationships of the Australasian open-holed trapdoor spiders (Araneae: Mygalomorphae: Nemesiidae: Anaminae): multi-locus molecular analyses resolve the generic classification of a highly diverse lineage. Zoological Journal of the Linnean Society 184: 407-452. doi: 10.1093/ zoolinnean/zlx111.

Hedin, M. and Bond, J.E. (2006). Molecular phylogenetics of the spider infraorder Mygalomorphae using nuclear rRNA genes (18S and 28S): conflict and agreement with the current system of classification. Molecular Phylogenetics and Evolution 41: 454-471. doi: 10.1016/j. ympev.2006.05.017.

Hogg, H.R. (1902). On some additions to the Australian spiders of the suborder Mygalomorphae. Proceedings of the Zoological Society of London 1902 (2): 121-142.
Katoh, K., Misawa, K., Kuma, K.-I. and Mityata, T. (2002). MAFFT: a novel method for rapid multiple sequence alignment based on fast Fourier transform. Nucleic Acids Research 30: 3059-3066. doi: 10.1093/nar/gkf436.

Koch, L. (1873). Die Arachniden Australiens. Vol. 1: 369-472. (Bauer und Raspe: Nürnberg).

Kumar, S., Stecher, G., Li, M., Knyaz, C. and Tamura, K. (2018). MEGA X: Molecular Evolutionary Genetics Analysis across computing platforms. Molecular Biology and Evolution 35: 1547-1549. doi: 10.1093/molbev/msy096.

Lanfear, R., Calcott, B., Ho, S.Y.W. and Guindon, S. (2012). PartitionFinder: combined selection of partitioning schemes and substitution models for phylogenetic analyses. Molecular Biology and Evolution 29: 1695-1701. doi: 10.1093/molbev/mss020.

Opatova, V., Hamilton, C.A., Hedin, M., Montes de Oca, L., Kral, J. and Bond, J.E. (2020). Phylogenetic systematics and evolution of the spider infraorder Mygalomorphae using genomic scale data. Systematic Biology 69: 671-707. doi: 10.1101/531756.

Rainbow, W.J. (1911). A census of Australian Araneidae. Records of the Australian Museum 9: 107-319.

Rainbow, W.J. and Pulleine, R.H. (1918). Australian trap-door spiders. Records of the Australian Museum 12: 81-169.

Raven, R.J. (1981). A review of the Australian genera of the mygalomorph spider subfamily Diplurinae (Dipluridae: Chelicerata). Australian Journal of Zoology 29: 321-363.

Raven, R.J. (1985a). A revision of the Aname pallida speciesgroup in northern Australia (Anaminae: Nemesiidae: Araneae). Australian Journal of Zoology 33: 377-409.

Raven, R.J. (1985b). The spider infraorder Mygalomorphae (Araneae): cladistics and systematics. Bulletin of the American Museum of Natural History 182: 1-180.

Simon, E. (1908). Araneae, $1^{\text {re }}$ partie. In: W. Michaelsen and R. Hartmeyer (eds), Die Fauna Südwest-Australiens 1: 359-446. (Gustav Fischer: Jena).

Stamatakis, A. (2006). RAxML-VI-HPC: maximum likelihood-based phylogenetic analyses with thousands of taxa and mixed models. Bioinformatics 22: 2688-2690. doi: 10.1093/bioinformatics/bt1446.

Talavera, G. and Castresana, J. (2007). Improvement of phylogenies after removing divergent and ambiguously aligned blocks from protein sequence alignments. Systematic Biology 56: 564-577. doi: 10.1080/10635150701472164.

Thackway, R. and Cresswell, I.D. (eds) (1995). An Interim Biogeographic Regionalisation for Australia: a framework for establishing the national system of reserves, version 4.0. (Australian Nature Conservation Agency: Canberra).

Wheeler, W.C., Coddington, J.A., Crowley, L.M., Dimitrov, D., Goloboff, P.A., Griswold, C.E., Hormiga, G., Prendini, L., Ramírez, M.J., Sierwald, P., Almeida-Silva, L., Alvarez -Padilla, F., Alvarez, F., Arnedo, M.A., Benavides Silva, L.R., Benjamin, S.P., Bond, J.E., Grismado, C.J., Hasan, E., Hedin, M., Izquierdo, M.A., Labarque, F.M., Ledford, J., Lopardo, L., Maddison, W.P., Miller, J.A., Piacentini, L.N., Platnick, N.I., Polotow, D., Silva-Dávila, D., Scharff, N., Szuts, T., Ubick, D., Vink, C.J., Wood, H.M. and Zhangi, J. (2017). The spider tree of life: Phylogeny of Araneae based on target-gene analyses from an extensive taxon sampling. Cladistics 33: 574-616. doi: 10.1111/cla.12182.

MANUSCRIPT RECEIVED 14 APRIL 2020; ACCEPTED 1 JULY 2020. 